\title{
Beyond Sex-Plus: Acknowledging Black Women in Employment Law and Policy
}

Jamillah Bowman Williams

Georgetown University Law Center, jamillah.williams@law.georgetown.edu

This paper can be downloaded free of charge from:

https://scholarship.law.georgetown.edu/facpub/2407

https://ssrn.com/abstract=3924267

Forthcoming in the Employee Rights \& Employment Policy Journal.

This open-access article is brought to you by the Georgetown Law Library. Posted with permission of the author. Follow this and additional works at: https://scholarship.law.georgetown.edu/facpub

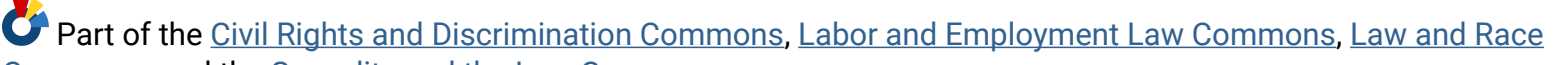
Commons, and the Sexuality and the Law Commons 


\title{
BEYOND SEX-PLUS: ACKNOLWEDGING BLACK WOMEN IN EMPLOYMENT LAW AND POLICY
}

\author{
BY JAMILLAH BOWMAN WILLIAMS*
}

\section{INTRODUCTION}

Even as Kamala Harris makes history by becoming the country's first Black woman Vice President, systemic racism and sexism remain pervasive in the United States, stifling life outcomes for Black women. ${ }^{1}$ In an intensely divided political climate, Black women workers bear the brunt of the emboldened racism and sexism of Trump's America, while at the same time, they also remain at the margins of broader social movements committed to racial and gender justice. The expansion of the \#MeToo movement in 2017 and the killing of George Floyd in 2020 led to broad activism, both online and on the ground, spurring mass protests, strikes, boycotts, and calls for legal reform. ${ }^{2}$ Workers, students, investors, community leaders, and politicians began demanding greater gender and racial equity. ${ }^{3}$ At the other extreme, former president Trump not only expressed hostility towards women and repeatedly failed to condemn white supremacists, but he also used his executive power to ban all anti-bias training that mentioned the concept of intersectionality. ${ }^{4}$ While the Biden-Harris administration and Democratic control of Congress offer more promise for Black women, it remains unclear whether this new leadership will produce policy reform and deeper structural change that will substantively improve employment outcomes for Black women.

This Article focuses on the challenges Black women continue to face when bringing intersectional claims, despite experiencing high rates of discrimination and harassment. It has been more than 30 years since Kimberlé Crenshaw published her pathbreaking article critiquing the inadequacy of antidiscrimination law in addressing claims at the intersection of race and sex

* J.D., Ph.D. in Sociology, Associate Professor of Law, Georgetown University Law Center and Faculty Director, Georgetown Law Workers' Rights Institute. I greatly appreciate the thoughtful feedback I received from colleagues at the Georgetown University Gender+ Justice Initiative Research Colloquium, the Lutie A. Lytle Black Women Law Faculty Workshop, and the Culp Colloquium. Thank you to my research assistants Victoria King, Denver Ellison, Austin Donohue, and Julia Anderson for their stellar team effort that helped make this article a reality during a challenging year navigating the pandemic.

${ }^{1}$ See e.g. Jocelyn Fyre, Racism and Sexism Combine to Shortchange Working Black Women, CTR. FOR AM. $\begin{array}{lllll}\text { PROGRESS } & \text { (Aug. } & 22, & 2019, & \text { 12:01 }\end{array}$ <https://www.americanprogress.org/issues/women/news/2019/08/22/473775/racism-sexism-combine-shortchangeworking-black-women>.

${ }^{2}$ See Jamillah Bowman Williams et al., \#MeToo as Catalyst: A Glimpse into 21 st Century Activism, 2019 U. CHI. LEGaL F. 371 (2019); Jamillah Bowman Williams et al., \#BlackLivesMatter-Getting from Contemporary Social Movements to Structural Change, 12 CAL. L. REv. ONLINE 1 (Jun. 2021).

${ }^{3}$ See Maria Torres-Soringer, The Fight for Equality at the Center of the George Floyd Case, ForD FounD. (June $9, \quad 2020), \quad<$ https://www.fordfoundation.org/just-matters/equals-change-blog/posts/the-fight-for-equality-at-thecenter-of-the-george-floyd-case>.

${ }^{4}$ President Biden reversed this ban on his first day in office. See Jessica Guynn, President Joe Biden Rescinds Donald Trump Ban on Diversity Training About Systemic Racism, USA TODAY (Jan. 26, 2021, 4:10 PM), $<$ https://www.usatoday.com/story/money/2021/01/20/biden-executive-order-overturns-trump-diversity-trainingban/4236891001>. 
discrimination. ${ }^{5}$ The new status quo has not resolved the problems that she documented, and has introduced a set of second generation intersectionality issues. Most significantly, many courts now recognize that Black women experience discrimination differently than do white women or Black men. Yet, despite the professionally and psychologically disabling consequences of such discrimination, judges have failed to develop a new analytic paradigm for addressing intersectional claims under Title VII. Likewise, Congress has failed to offer a legislative solution, and the Equal Employment Opportunity Commission provides scant guidance for employees, employers, and attorneys attempting to navigate these claims. Even the recent flurry of \#MeToo-inspired state legislative reforms miss the opportunity to address this persistent problem.

This isn't to say that no workable approaches exist. They do, they just require a close examination of the current approaches, and then taking a step back to re-imagine how we currently conceptualize antidiscrimination law. This Article is the first to identify and critique the four primary approaches used by courts of appeals to analyze intersectional claims, and the first to assess the potential impact of the Supreme Court's decision in Bostock v. Clayton on intersectional race and sex claims under Title VII. In subsequent articles, I will build on these findings to propose a better framework for courts to follow when analyzing intersectional discrimination and harassment cases.

Part II describes how intersectional discrimination and harassment shape the workplace experiences of Black women. Part III examines how discrimination and harassment are analyzed under Title VII and how existing legal frameworks are problematic for Black women plaintiffs. Part IV provides an overview of the current state of the law, focusing on how courts diverge in their approach to intersectional claims, resulting in confusion for employees, employers, and attorneys, and injustice for some plaintiffs. Part V analyzes more recent trends in courts and state legislatures, including the impact of Bostock v. Clayton County, the concept of discriminatory harassment in state law, and the reasonable Black woman standard. Part VI concludes with a discussion of future directions for antidiscrimination law, including how reform efforts can better address the existing gaps in the law to make Title VII and related state policies more effective at protecting Black women workers.

Despite vocal resistance to Critical Race Theory, the ongoing movement for racial justice and increased receptiveness to address systemic racism following the mass protests in 2020, make this an opportune time to renew our discussion of intersectionality and reshape the meager analytical framework of antidiscrimination law. This Article lays the foundation for future research and second generation law and policy proposals that will take crucial steps towards finally acknowledging and addressing the real discrimination Black women face.

\section{THE INTERSECTIONAL EXPERIENCES OF BLACK WOMEN AT WORK}

Black women are disproportionately impacted by a multitude of employment challenges. ${ }^{6}$ This

5 Kimberlé Crenshaw, Demarginalizing the Intersection of Race and Sex: A Black Feminist Critique of Antidiscrimination Doctrine, Feminist Theory, and Antiracist Politics, 1989 U. CHI. LEGAL F. 139 (1989).

${ }^{6}$ Mark Paul et al., Returns in the Labor Market: A Nuanced View of Penalties at the Intersection of Race and Gender 3-4 (Wash. Ctr. for Equitable Growth, Working Paper, 2018), <https://equitablegrowth.org/workingpapers/intersectionality-labor-market> (scroll down and click "download file") (discussing why intersectionality 
includes a substandard minimum wage, ${ }^{7}$ an ongoing pay gap despite increasing levels of education, and inadequate health and safety measures for frontline workers during COVID-19. ${ }^{8}$ Thus, Black women are subject to deeply entrenched forces of systemic racism and sexism at the structural level and at the interpersonal level. They also face unique stereotypes and biases that neither white women nor Black men face. This leads Black women to encounter high rates of discrimination and harassment in the workplace that can take many forms. ${ }^{9}$ Yet, employment law and policy continues to fail Black women workers who seek to bring discrimination and harassment claims under Title VII of the Civil Rights Act of 1964. ${ }^{10}$

Over thirty years ago, Kimberlé Crenshaw coined the term intersectionality and created a theoretical framework to critique antidiscrimination laws and policies for failing to properly acknowledge compounded forms of discrimination based on the intersection of two or more protected categories, such as race and sex. ${ }^{11}$ Current antidiscrimination law is especially problematic for Black women, many of whom report not centrally identifying with race or sex, but with a racialized gender identity inextricably intertwining the two. ${ }^{12}$ Consider the case of Emerald-

theory should be included in analyses of labor market discrimination and deepening the understanding of how the possession of one socially salient identity such as being a woman or being black may oversimplify the effects of the complex of social identities that interact in ways which researchers still need to identify.)

${ }^{7}$ See Nicole Bateman \& Martha Ross, Why Has COVID-19 Been Especially Harmful for Working Women?, BROOKINGS INST. (Oct. 2020), <https://www.brookings.edu/essay/why-has-covid-19-been-especially-harmful-forworking-women> ("[B]efore COVID-19, nearly half of all working women $-46 \%$ or 28 million - worked in jobs paying low wages, with median earnings of only $\$ 10.93$ per hour. The share of workers earning low wages is higher among Black women (54\%) and Hispanic or Latina women (64\%) than among white women (40\%), reflecting the structural racism that has limited options in education, housing, and employment for people of color."); Allana Akhtar, Lower Pay, More Harassment: How Work in America Failed Women of Color in the 2010s, BUS. INSIDER (Dec. 18, 2019, 7:57 AM), <https://www.businessinsider.com/how-work-is-failing-women-of-color-2019-10\#black-andhispanic-women-are-far-more-likely-to-work-low-paying-jobs-3> ("Black women . . . are more likely to work in food service, domestic work, and home healthcare - all some of the worst paying occupations in the country.").

8 See Black Woman Aren't Paid Fairly, and that Hits Harder in an Economic Crisis, LEAN IN, <https://leanin.org/data-about-the-gender-pay-gap-for-black-women> (last visited May 14, 2021); Andre M. Perry, To Protect Black Women and Save America from Itself, Elect Black Women, BROOKINGS InST. (July 2020), <https://www.brookings.edu/essay/to-protect-black-women-and-save-america-from-itself-elect-black-women> (finding that "Black women have lower earnings than Black men, as well as white men and women"); Adia Harvey Wingfield, Women Are Advancing in the Workplace, but Women of Color Still Lag Behind, BROOKINGS Inst. (Oct. 2020), <https://www.brookings.edu/essay/women-are-advancing-in-the-workplace-but-women-of-color-still-lagbehind> ("[White w]omen make 79 cents for every dollar men earn . . . [b]ut Black women earn only 64 cents on the dollar); Fyre, supra note 1.

9 Asha DuMonthier, Chandra Childers \& Jessica Milli, InST. FOR WOMEN's POL'y Rsch. \& NAT'L DOMESTIC WORKers All., THE Status OF BlaCk WOMEN IN THE United States 24-29 (2020), <https://iwpr.org/wp-content/uploads/2020/08/The-Status-of-Black-Women-6.26.17.pdf> (noting that Black women experience higher rates of employment and labor market and "improved enforcement of anti-discrimination and equal opportunity laws" is needed).

${ }^{10}$ Civil Rights Act of 1964, 42 U.S.C. $\$ 2000$ e.

${ }^{11}$ See generally Kimberlé Crenshaw, Demarginalizing the Intersection of Race and Sex: A Black Feminist Critique of Antidiscrimination Doctrine, Feminist Theory, and Antiracist Politics, 1989 U. CHI. Legal F. 139.

${ }^{12}$ Martinique K. Jones \& Susan X. Day, An Exploration of Black Women's Gendered Racial Identity Using a Multidimensional and Intersectional Approach, 79 SEX Roles 1, 2 (2017) ("Studies establish that gendered racial identity is more salient and important to Black women than are race and gender independently. When compared to other women, Black women's understanding of self at the crux of race and gender is nuanced because of their two 
Jane Hunter - a thirty-seven-year-old African immigrant from Illinois. Hunter described instances where white men in power made sexual references to her skin-color, calling her "dark chocolate," and stating, "I want to get a little piece of chocolate." 13 In 2017, two Ford plants in Chicago settled a second lawsuit with Black women plaintiffs for sex and racial harassment. ${ }^{14}$ Many of the female employees who eventually sued Ford, felt doubly victimized - propositioned and denounced as sluts while also being called "black bitches" and other racial slurs. ${ }^{15}$ Or take Alexia Agnant, a black saleswoman born in Jamaica. ${ }^{16}$ Despite a strong performance record, she was subject to adverse employment actions by her white male supervisor, who commented on her nail polish and appearance every trip she made to the office, asking if her braided hair was "from a dead person," and calling her "Sheneneh" to "insinuate[] that [she] was a ghetto black woman."17 These narratives demonstrate how Black women workers in fields dominated by white men may experience intersectional discrimination and harassment because of their race and sex.

Research shows that low-wage Black women, like those working in the fast-food industry, "are more likely to report negative sexual attention than white women . . . . [It is possible that] this phenomenon occurs because women of color face a 'double jeopardy' of being both women and ethnic minorities, groups more susceptible to harassment." 18 Take Barbara Johnson, for example, who began working at McDonald's in 2017 at age seventeen. ${ }^{19}$ As a young, Black fast food worker her sexual harassment experiences began on her very first day. ${ }^{20}$ In detailing her encounters, she recalled: "He made comments about how juicy my lips was, how cute I am, how my uniform fit me in all the right places, how I'm thick in all the right places. He'd look at me and lick his lips. It all made me feel uncomfortable, like I was unsafe." ${ }^{21}$ She was groped on multiple occasions and her manager often witnessed her continued harassment yet laughed it off. ${ }^{22}$ Although many Black

oppressed identities, both of which shape each other. Furthermore, the oppression of women of color endure because of their race and gender perhaps enhances the salience of their intersectional identity and informs the way they construct and assign meaning to this identity (e.g., resilience and strength).").

13 Jessica Prois \& Carolina Moreno, The \#MeToo Movement Looks Different for Women of Color. Here Are 10 Stories, HufFINGTON POST (Jan. 2, 2018, 9:20 AM), <https://www.huffpost.com/entry/women-of-color-metoo_n_5a442d73e4b0b0e5a7a4992c>.

${ }^{14}$ Susan Chira \& Catrin Einhorn, How Tough Is It to Change a Culture of Harassment? Ask Women at Ford, N.Y. TIMES (Dec. 19, 2017), <https://www.nytimes.com/interactive/2017/12/19/us/ford-chicago-sexualharassment.html> ("Bosses and fellow laborers treated them as property or prey. Men crudely commented on their breasts and buttocks; graffiti of penises was carved into tables, spray-painted onto floors and scribbled onto walls. They groped women, pressed against them, simulated sex acts or masturbated in front of them. Supervisors traded better assignments for sex and punished those who refused.").

${ }^{15} I d$.

${ }^{16}$ Agnant v. CSC Holdings, LLC, No. 17-cv-3349, 2020 WL 2615907, at*1 (E.D. NY May 20, 2020).

${ }^{17}$ Id. Alexia's supervisor also referred to her as "Sheneneh," a reference to a comedic parody of a "ghetto" black woman played by actor Martin Lawrence. The court allowed her Title VII race discrimination to survive summary judgement, but not her sex discrimination claim. Id. at *9-12.

18 See Akhtar, supra note 6.

19 Tim Rowden, Tired of on-the-Job Sexual Harassment, Workers Demand Change at McDonald's, LAB. TRIB. (Oct. 1, 2018), <https://labortribune.com/tired-of-on-the-job-sexual-harassment-workers-demand-change-atmcdonalds>.

${ }^{20} I d$.

${ }^{21} I d$.

${ }^{22}$ As long-time employees of fast-food franchises, Black women employees rely on these low-wage positions to help them cover rent, food, basic child-care, and other household expenses. See Kalena Thomhave, McDonald's Workers Strike to Demand Response to Sexual Harassment Charges, AM. ProsPECT (Sept. 20, 2018), 
women and other women of color mobilized to strike and file a class action lawsuit against McDonald's for this type of harassment, ${ }^{23}$ the COVID-19 pandemic has created even greater economic precarity, which may intensify the marginalization of these workers. Since the start of the pandemic, female workers have reported a noticeable uptick in sexualized comments from customers and also experienced or witnessed increased sexual harassment in the food industry. ${ }^{24}$

Black women from across the country confront similar workplace realities where both their race and gender identities contribute to their experiences of workplace discrimination and harassment. However, these experiences do not fit narrowly into the Title VII antidiscrimination frameworks used by courts to assess claims. Instead of recognizing that race and gender-based discrimination often co-exist for women of color, judges too often parse out specific conduct as based on race" or "based on sex," instead of considering the totality of the circumstances. We need to close the gap between the legal definitions of discrimination and the lived experience of Black women workers unique positionality whose marginalization within the workplace are defined by the intersectional nature of their race and sex. ${ }^{25}$

In other words, Black women workers experience discrimination in distinct ways that require Courts to undergo a more complex and nuanced analysis that reviews the aggregate nature of overlapping harms. However, judges and lawmakers have been extremely reluctant to do so in both the discrimination and harassment contexts. Under the current intersectionality legal framework, a Black women worker, like Emerald Jane-Hunter, Barbara Johnson, or Alexia Agnant, who experiences discrimination and/or harassment because of her race and sex must decide whether to bring multiple, separate claims under Title VII for each protected category or an intersectional claim, and with either option, they have a high risk of failure at the summary judgment stage. While the Equal Employment Opportunity Commission (EEOC) has identified intersectional discrimination as a potential claim, it has not provided any specific guidance to courts on how to interpret Title VII to allow and evaluate this cause of action. ${ }^{26}$

<https://prospect.org/labor/mcdonald-s-workers-strike-demand-response-sexual-harassment-charges>. In a recent 2020 case, two additional McDonald's employees, who are Black women, filed a class action lawsuit against the company for their experiences of harassment and retaliation. See Michelle Chen, Fed Up: Women Fast-Food Workers Fight Back, Ms. MAG. (Mar. 28, 2015), <https://msmagazine.com/2015/03/28/fed-up-women-fast-food-workersfight-back>; Lisa Jennings, McDonald's Corp. Faces New Charges of Sexual Harassment and Retaliation, NATION'S RESTAURANT NEWS (Apr. 13, 2020), <https://www.nrn.com/quick-service/mcdonald-s-corp-faces-new-chargessexual-harassment-and-retaliation>.

${ }^{23}$ Chen, supra note 22; Jennings, supra note 22.

${ }^{24}$ See generally CATHARINe A. MACKInNOn \& Louise FitzGERALD, U.C. Berkeley FoOd LAB. RSCH. CTR. \& BARry COMMONER CTR. FOR HeAlth \& ENV., TAKE YOUR MASK OFF SO I KNOW HOW MuCH TO TIP YOU: SERVICE WORKERS' EXPERIENCE OF HEALTH \& HARASSMENT DURING COVID-19 (2020), <https://onefairwage.site/wpcontent/uploads/2020/12/OFW_COVID_WorkerExp-1.pdf>.

${ }^{25}$ Dan Cassino \& Yasemin Besen-Cassino, Race, Threat and Workplace Sexual Harassment: The Dynamics of Harassment in the United States, 1997-2016, 26 GENDER, WORK \& ORG. 1221, 1222 (2019) ("[S] exual harassment is both a legal issue and a lived experience.").

${ }^{26}$ Yvette N.A. Pappoe, The Shortcomings of Title VII for the Black Female Plaintiff, 22 U. PA. J.L. \& Soc. Change 1, 18 (2019); Bradley Allan Areheart, Intersectionality and Identity: Revisiting a Wrinkle in Title VII, 17 GEO. MASON U. CIV. RTS. L.J. 199, 232-34 (2006). 


\section{OVERVIEW OF TITLE VII INTERSECTIONAL DISCRIMINATION AND HARASSMENT CLAIMS}

Under the current Title VII analytical frameworks, courts struggle to analyze intersectional claims and address the compounding effects of race and sex. As a result, Black women plaintiffs fail to receive adequate relief. Courts primarily evaluate intersectional race and sex claims as mutually exclusive legal categories. In doing so, white women and Black men are able to vindicate their harms while Black women are often left with inadequate remedies.

The MeToo movement has sparked some momentum in gender equity legislation at the state level, yet these reforms have also failed to address intersectionality. Of the many reforms proposed and passed across the United states, not one explicitly addresses intersectionality. ${ }^{27}$ The overwhelming majority of state reform efforts include language to better protect those bringing sex harassment claims, but not those also experiencing racial discrimination and harassment. Any reform that does not acknowledge intersectionality cannot adequately address the way Black women are commonly subordinated based on their race and sex, and Black women will remain largely unprotected. ${ }^{28}$

Title VII of the Civil Rights Act of 1964 prohibits discrimination based on an individual's race, color, religion, sex, or national origin. ${ }^{29}$ While Black women experience disproportionately high rates of discrimination and harassment, they face many hurdles even before they can consider filing a Title VII lawsuit. ${ }^{30}$ For example, many positions dominated by women of color are not protected by federal law. ${ }^{31}$ This includes domestic workers, including nannies, house cleaners, and home care workers, where Black women are overrepresented, ${ }^{32}$ and the increasing number of Black women working in the gig economy. Other roadblocks to state and federal court include rigid statute of limitations, increased mandatory arbitration, and difficulty finding an attorney to take intersectional claims. ${ }^{33}$

For the Black women who defeat the odds to get cases filed, the Title VII statutory framework and judicial interpretation are ill equipped to address intersectional discrimination and harassment. Plaintiffs alleging discrimination based on multiple protected categories are more likely to lose on

${ }^{27}$ See infra, Part VI.

${ }^{28}$ See generally Crenshaw, supra note 10.

2942 U.S.C. § 2000e-2(a).

${ }^{30}$ See generally Tanya Kateri Hernandez, A Critical Race Feminism Empirical Research Project: Sexual Harassment \& the Internal Complaints Black Box, 39 U.C. DAVIS L. REV. 1235 (2006); see also Ashleigh Shelby Rosette et al., Intersectionality: Connecting Experiences of Gender with Race at Work, 38 RsCH. ORG. BEHAV. 1, 13 (2018); Pat K. Chew \& Robert E. Kelley, Unwrapping Racial Harassment Law, 27 BERKELEY J. EMP. \& LAB. L. 49, 60 (2006).

${ }^{31}$ Debra L. Ness, Domestic Workers Bill of Rights Would Help Provide Dignity, Respect and Workplace Protections to Millions, NAT'L P'SHIP FOR WOMEN \& FAMILIES (July 24, 2019), <https://www.nationalpartnership.org/our-impact/blog/general/domestic-workers-bill-of-right-provide-dignityrespect-workplace-protections-to-millions.html>.

${ }^{32}$ Data shows that there are over 2.2 million domestic workers, with over half of these workers holding positions as home care aids. 91.5 percent of these workers are women, with an overrepresented number of these workers being Black women. See Julia Wolfe, Domestic Workers Are at Risk During the Coronavirus Crisis, ECON. POL'Y InST. (Apr. 8, 2020, 10:00 AM), <https://www.epi.org/blog/domestic-workers-are-at-risk-during-the-coronavirus-crisisdata-show-most-domestic-workers-are-black-hispanic-or-asian-women>.

${ }^{33}$ Infra Part VI. 
summary judgement compared to those alleging claims based on one protected category. ${ }^{34}$ Further, plaintiffs alleging intersectional discrimination who make it beyond summary judgment are only half as likely to win their cases, compared to other type of plaintiffs. ${ }^{35}$ Outcomes are even more bleak for Black women bringing these claims. Rachel Kahn Best and co-authors found that women of color who make it beyond the summary judgment stage are generally the least likely to win their cases, even less than white men alleging discrimination. ${ }^{36}$ Thus, while Title VII was enacted to eliminate employment discrimination based on race, color, national origin, race, or religion, in reality it is not providing a remedy for the many Black women plaintiffs experiencing intersectional discrimination and harassment.

Intersectional discrimination claims most commonly arise in the context of disparate treatment and are analyzed with the McDonnell Douglas framework established by the Supreme Court. ${ }^{37}$ Following McDonnell Douglas, a plaintiff must first establish a prima facie case by showing that: (1) she is member of a protected class; (2) she is qualified; (3) she was subject to an adverse employment action; and (4) other circumstances give rise to an inference of discrimination. ${ }^{38}$ For the fourth prong, "most courts require the plaintiff to show evidence of a similarly situated 'comparator' outside of their protected class" who was not treated adversely. ${ }^{39}$ Who the court perceives to be an "appropriate" comparator becomes a tricky inquiry for Black women bringing intersectional sex and race claims. ${ }^{40}$

Black women may also encounter "unintentional" intersectional discrimination, analyzed using a disparate impact burden shifting framework. ${ }^{41}$ This is a more subtle form of exclusion that occurs when a seemingly neutral policy or practice unduly disadvantages individuals based on their protected class. ${ }^{42}$ For example, minimum height requirements are facially neutral, but may have a disparate impact on women. A policy or practice that is neutral on its face can also disproportionately exclude Black women in particular. ${ }^{43}$ For example, a policy prohibiting all-

${ }^{34}$ Minna Kotkin, Diversity and Discrimination a Look at Complex Bias, 50 WM. \& MARY L. REV. 1439,1459 (2009) (noting that 96 percent of intersectional employment discrimination claims lose on summary judgment as compared to 73 percent of cases alleging discrimination based on one protected group).

35 Rachel Kahn Best et al., Multiple Disadvantages: An Empirical Test of Intersectionality Theory in EEO Litigation, 45 LAW \& SoC'Y REV. 991, 1009 (2011) (Women of color win 15 percent of cases, compared to 31 percent for white men, and 38 percent for white women).

${ }^{36} I d$.

37 McDonnell Douglas Corp. v. Green, 411 U.S. 792 (1973). This article breaks this analysis out into three categories: (1) intersectional "discrimination,"(2) analyzed as disparate treatment or disparate impact, and (3) intersectional harassment (most often hostile environment) analyzed separately, although technically it is also a form of discrimination.

${ }^{38}$ Furnco Constr. Corp. v. Waters, 438 U.S. 567, 575-76 (1978); Giles v. Univ. of Toledo, 286 F. App’x 295,303 (6th Cir. 2008); Prescott v. Higgins, 538 F.3d 32, 40-41 (1st Cir. 2008); Anderson v. Westinghouse Savannah River Co., 406 F.3d 248, 268-69 (4th Cir. 2005); Stella v. Mineta, 284 F.3d 135, 144-45 (D.C. Cir. 2002 ).

${ }^{39}$ See Stephanie Bornstein, Equal Work, 77 MD. L. REV. 581, 604 (2018) (“[F]or example a male employee for a sex claim and a white employee for a race claim.”).

${ }^{40}$ Carole H. Hofstein, African American Women and the Limits of Law and Society, 1 CARDOZO WOMEN'S L.J. 373, 375 (1994) (explaining how an employer can rebut black women's race and gender discrimination claims by comparing her to black men and white women).

${ }^{41}$ See generally Griggs v. Duke Power Co., 401 U.S. 424 (1971).

42 See generally id.

${ }^{43}$ Cf. Rogers v. Am. Airlines, Inc., 527 F. Supp. 229, 232 (S.D.N.Y. 1981) (considering a policy prohibiting all- 
braided hairstyles will disproportionately impact black women. ${ }^{44}$ In disparate impact cases, once a plaintiff demonstrates that a policy or practice has a disproportionately harmful effect on a protected class, ${ }^{45}$ the employer must show the policy or practice is job related for the position in question and consistent with business necessity. ${ }^{46}$ Even with that showing, the employer will lose if the plaintiff can show that another less discriminatory alternative requirement would suffice. ${ }^{47}$

A common employer defense to intersectional discrimination claims brought by Black women is that the race claim fails because Black men are not discriminated against and the sex claim fails because white women are not discriminated against. For example, in Jefferies $v$. Harris County Community Action Ass' $n$, the district court failed to consider the combined effect of race and sex discrimination on the plaintiff, who, as a Black female, was repeatedly passed over for promotions. ${ }^{48}$ Despite her qualifications, the district court ruled against the plaintiff, relying on the fact that: (1) the person who received the promotion Jefferies sought was black and (2) the employer had presented statistical evidence that a number of white females and Black males on the employer's staff. ${ }^{49}$ On appeal, the Fifth Circuit remanded the case, stating that Black female plaintiffs may still be discriminated against "in the absence of discrimination against black men or white women." 50 Thus, adherence to this comparator-based approach can be particularly problematic for Black women bringing intersectional claims because it prevents the more contextual approach that may be required to address questions of intersectionality.

For intersectional discrimination claims, the EEOC takes the position that Title VII prohibits discrimination not solely for one protected trait, but also prohibits discrimination because of the intersection of two or more bases. ${ }^{51}$ Specifically, the EEOC notes that Title VII prohibits discrimination against Black women even if the employer does not discriminate against white women or Black men. Thus, the EEOC acknowledges that there is a particular way in which Black women may experience employment discrimination due to their identity being at the intersection of being Black and being women.

Intersectional harassment claims are most commonly analyzed under a hostile work environment theory. To bring an intersectional harassment claim, a Black woman plaintiff must

braided hairstyle disproportionately impacted black women, but noting that plaintiff had failed to allege that allbraided hairstyles were worn predominantly by Black people); Carla D. Pratt, Sisters in Law: Black Women Lawyers' Struggle for Advancement, 2012 MICH. ST. L. REV. 1777, 1782-85 (expectations for maintaining a traditional professional image impose more demands on black women); Melissa Pascualini, Ban the Box: Breaking Barriers to Employment in the Private Sector, 37 HofsTRA LAB. \& EMP. L.J. 255, 259-60 (2019) (hiring policies that evaluate candidates based on criminal history can disproportionately affect black women).

${ }^{44}$ See Rogers, 527 F. Supp. at 232.

45 Usually by statistical comparison, which the defendant employer can challenge.

${ }^{46}$ Griggs, 401 U.S. at 431-32, 436.

4742 U.S.C. $\$ 2000 \mathrm{e}-2(\mathrm{k})(1)(\mathrm{A})(\mathrm{ii}),(1)(\mathrm{C})$.

48 Jefferies v. Harris Cnty. Cmty. Action Ass'n, 615 F.2d 1025, 1032 (5th Cir. 1980).

${ }^{49} I d$.

${ }^{50} I d$.

51 See EEOC Compliance Manual § 15(IV)(C) (Apr. 19, 2006), <https://www.eeoc.gov/laws/guidance/section15-race-and-color-discrimination\#IVC> ("Title VII prohibits discrimination not just because of one protected trait (e.g. race), but also because of the intersection of two or more protected bases (e.g. race and sex). . . The law also prohibits individuals from being subjected to discrimination because of the intersection of their race and a trait covered by another EEO statute - e.g., race and disability, or race and age."). 
prove that she was subject to a hostile workplace because of her protected category. Here, Black women may experience harassment, subordination, and other exploitation that is both racial and because of their sex. Common defenses to intersectional harassment claims brought by Black women are that (1) they didn't complain and (2) the harassment they experienced wasn't 'severe or pervasive." For the first defense, in cases where harassment occurs, but there is no termination, demotion, or other tangible employment action taken by the supervisor, the employer may assert an affirmative defense to defeat liability or damages. The affirmative defense created by the Supreme Court in Faragher v. City of Boca Raton and Burlington Industries, Inc. v. Ellerth

comprises two necessary elements: (a) that the employer exercised reasonable care to prevent and correct promptly any illegal harassing behavior, and (b) that the plaintiff employee unreasonably failed to take advantage of any preventive or corrective opportunities provided by the employer or to avoid harm otherwise. ${ }^{52}$

Both elements may not always be required. ${ }^{53}$

Employers also commonly argue that the conduct falls short of meeting the standard of being severe or pervasive enough to be actionable. ${ }^{54}$ Under this defense, courts have barred causes of action because they don't find them objectively intimidating or offensive. ${ }^{55}$ Many lower courts have interpreted this standard to require conduct to be both severe and pervasive. ${ }^{56}$ This standard is set at such a high bar that conduct is rarely found to be threatening, humiliating, or abusive enough to support a claim, even in some cases when the facts would give rise to a criminal

${ }^{52}$ Faragher v. City of Boca Raton, 524 U.S. 775, 807 (1998); Burlington Indus., Inc. v. Ellerth, 524 U.S. 742,765 (1998); see also Phillips v. Taco Bell Corp., 156 F.3d 884, 887-88 (8th Cir. 1998) (quoting Faragher and Ellerth); Rorie v. United Parcel Serv., Inc., 151 F.3d 757, 762 (8th Cir. 1998) (quoting same).

${ }^{53}$ See McCurdy v. Ark. State Police, 375 F.3d 762, 771-74 (8th Cir. 2004). Whether an individual is a "supervisor" for purposes of vicarious liability under Faragher and Ellerth may also be a contested issue. A supervisor "must be . .. empowered [by the employer] to take tangible employment actions against the victim, i.e., to effect a "significant change in employment status, such as hiring, firing, failing to promote, reassignment with significantly different responsibilities, or a decision causing a significant change in benefits." Vance v. Ball State Univ., 570 U.S. 421,431 (2013).

${ }^{54}$ Harris v. Forklift Sys., Inc., 510 U.S. 17, 21-23 (1993) (holding that to be severe or pervasive enough to alter the terms or conditions of employment, the harassment must "create an objectively hostile or abusive work environment - an environment that a reasonable person would find hostile or abusive," but need not lead to physical or psychological impairment, and identifying the following (non-exhaustive) list of factors: "the frequency of the discriminatory conduct; its severity; whether it is physically threatening or humiliating, or a mere offensive utterance; and whether it unreasonably interferes with an employee's work performance.").

55 Judith J. Johnson, License to Harass Women: Requiring Hostile Environment Sexual Harassment to Be "Severe or Pervasive" Discriminates Among "Terms and Conditions" of Employment, 62 MD. L. REV. 85, 111 (2003). Despite Harris' non-exhaustive factors, "[m]any courts . . . are requiring that the conduct be severe, frequent, and physically threatening. In effect, these courts are requiring that the conduct be severe and pervasive, and some courts also require that the plaintiff show that her job was tangibly affected." Id.; Kenyon v. W. Extrusions Corp., No. CIV. A. 3:98CV2431L, 2000 WL 12902, at*6 (N.D. Tex. Jan. 6, 2000) (stating that although the conduct in the fifty alleged incidents of harassment was sufficiently severe or pervasive, the plaintiff failed to show in addition that the conduct "undermined her workplace competence.").

56 Jamillah Bowman Williams, Maximizing \#MeToo: Intersectionality and the Movement, 62 B.C. L. REV., 1797

(2021) (manuscript at 45), <https://scholarship.law.georgetown.edu/cgi/viewcontent.cgi?article=3299 \&context=facpub>. 
offense. ${ }^{57}$ This is particularly problematic for intersectional claims when the courts force plaintiffs to divide incidents up into separate claims: for sex and then for race. After artificially disaggregating, they then hold that the incidents alleged for race are not sufficiently severe or pervasive for a race claim, and those that are alleged as related to sex, are not severe or pervasive enough for a sex claim to proceed. This analysis ignores the overlapping nature of the harassment and the totality of the circumstances standard established in Harris v. Forklift Systems, Inc. ${ }^{58}$

As it pertains to intersectional harassment claims, the EEOC does not explicitly carve out a section in its guidance memo for those claims. Instead, the EEOC, in its examples for racial harassment, describes a Black woman named Kyra, stating that "[ $\mathrm{t}] \mathrm{he}$ evidence supports the conclusion that Kyra was subjected to a hostile work environment because of her race, sex, or the intersection of both, in light of the pattern of offensive comments and evidence that the bias altered the terms and conditions of Kyra's employment," thus hinting that such a claim can be made. ${ }^{59}$ The guidance does not, however, describe how this type of intersectional claim should be analyzed. ${ }^{60}$

\section{Muddy WATERS: COURTs REMAin SPLit On How to ANALYZE InTERSECTIONAL Claims}

Currently, circuit courts have adopted four somewhat distinct approaches to Title VII intersectional race and sex claims. These approaches are: (1) separate claims for each protected trait; (2) sex-plus and/or race-plus framework; (3) Black women as a distinct, protected category; or (4) a totality/aggregate approach. The remaining circuits are inconsistent in how they analyze intersectional claims.

\section{A. Narrow Interpretation of Title VII}

Sometimes referred to as the DeGraffenreid approach, the Fourth and Eighth Circuits have interpreted the language and intent of Title VII as requiring Black women workers to sue on the separate bases of race or sex discrimination rather than pursue an intersectional discrimination race and sex claim. ${ }^{61}$ When a Black woman plaintiff alleges that her workplace experience is the result of her race and sex, she is required to bisect her identity and experiences in a way that does not reflect her reality in order to bring a claim. These claims may also then be perceived as weaker once they are bifurcated in this way.

For example, the Eighth Circuit will not recognize an intersectional claim from a Black woman that combines two causes of action under the false assumption that doing so will create a "special" sub-category that would receive a "super-remedy." 62 In DeGraffenreid, five Black women alleged that the "last hired first fired" seniority system used by General Motors (GM) had a disparate

${ }^{57}$ Johnson, supra note 53, at 111.

${ }^{58}$ See Harris, 510 U.S. at 21-23.

${ }^{59}$ EEOC Compliance Manual § 15(VII)(A), ex. 19 (Apr. 19, 2006), https://www.eeoc.gov/laws/guidance/section15-race-and-color-discrimination\#VIIA (scroll down to Example 19).

${ }^{60} I d$.

${ }^{61}$ See DeGraffenreid v. Gen. Motors Assembly Div., 413 F. Supp. 142, 143 (E.D. Mo. 1976), aff'd in part, rev'd in part on other grounds, 558 F.2d 480 (8th Cir. 1977) (finding that an intersectional race and sex claim was beyond the intent of the Title VII statute and would, in essence, create a new subgroup that would provide Black women a "super-remedy").

${ }^{62} I d$. at 143. 
impact on Black women. Prior to 1964, GM did not hire Black women, and all of the Black women who were hired after that point were terminated during a recession due to GM's lay-off policy. ${ }^{63}$ The court granted summary judgment to GM for the sex claim and dismissed the race claim without prejudice, finding that a consideration of both would afford greater relief to Black women than other potential plaintiffs. ${ }^{64}$

Under this framework, the Eighth Circuit continues to parse out which protected trait motivates the alleged discriminatory conduct. For example, in Carter v. Chrysler Corp., a Black woman plaintiff, Gloria S. Carter, sued her employer and union under Title VII after experiencing race and sex harassment in her job as an assembly line worker. ${ }^{65}$ She produced evidence that her white, male co-workers directed sexual and racial epithets towards her and repeatedly disrupted her work performance by placing "[a] picture of a naked man, dead animals, threatening notes, foul-smelling material, and debris" in her work area. ${ }^{66}$ Even with her strong evidence of discrimination, the court focused on disaggregating her claims, writing: "There is no dispute that Carter is a member of protected classes or that she was subject to unwelcome harassment, but the parties disagree about whether the hostile acts directed at Carter were because of her race or gender." ${ }^{\circ 7}$ By concerning itself with making this distinction, the Eight Circuit misinterprets the spirit of Title VII and minimizes the significance of the harassment being the result of Gloria's race and sex.

The Eighth Circuit's reasoning reflects a flawed understanding of intersectionality theory as somehow harmful to white women, Black men, and other individuals perceived to have a singular protected trait. In reality, the Eighth Circuit's failure to recognize combined race and sex claims under Title VII leaves Black women, as members of multiple marginalized groups, in an untenable position. By requiring them to separate the harms they experience and choose a race or sex claim, Black women are asked to define their experience based on outcomes of white women or Black men. ${ }^{68}$ This approach is the narrowest interpretation of Title VII across the circuits and unnecessarily dismisses legitimate Title VII claims brought by Black women workers.

The Fourth Circuit has also analyzed Black female plaintiffs' racial and sexual harassment claims separately. For example, in Mosby-Grant v. City of Hagerstown, the Court analyzed a Black woman's racial and sexual harassment claims separately, while declining to "address whether she would have been able to sustain a 'hybrid' sex and race claim under Title VII because she had not raised the issue. ${ }^{~} 69$ In that case, the plaintiff, Tiffany Mosby-Grant, was a Black female recruit in the Police Academy. ${ }^{70}$ Throughout her training she was the only woman and one of two Black recruits. ${ }^{71}$ During the isolating experience, Tiffany overheard racist and sexist statements, received

${ }^{63}$ Mary Elizabeth Powell, The Claims of Women of Color Under Title VII: The Interaction of Race and Gender, 26 GoldEN GATE UNIV. L. REV. 413, 417 (1996).

${ }^{64}$ DeGraffenreid, 413 F. Supp at 145.

${ }^{65}$ See Carter v. Chrysler Corp., 173 F.3d 693 (8th Cir. 1999).

${ }^{66} \mathrm{Id}$. at 702 .

${ }^{67} \mathrm{Id}$. at 700 (emphasis added).

${ }^{68}$ See Pappoe, supra note 25, at 10.

${ }^{69}$ Mosby-Grant v. City of Hagerstown, 630 F.3d 326, 335-37 \& n.4 (4th Cir. 2010) (emphasis in original).

${ }^{70} \mathrm{Id}$. at 329 (also finding that in recent years, there had been no African Americans and only four women among the police academy recruits).

${ }^{71}$ See id. 
complaints from other recruits that she received special treatment because she was a woman, and was the target of negative comments by her peers. ${ }^{72}$ Tiffany excelled through training until the final weeks where she failed her final firearms test, which heightened the harassment. ${ }^{73}$

When presented with her appeal, the Fourth Circuit reviewed Tiffany's intersectional claims for distinct evidence that could support either a sex or race claim. In explaining its review, the Court wrote:

[w] e are keenly aware of the difficulties inherent in parsing out Title VII claims brought by individuals, e.g., African American women, who fall under more than one protected class. We also recognize that a hostile work environment claim can be bolstered by relying on evidence of a workplace tainted by both sex and racial discrimination .... Nevertheless, there are now two distinct counts before us, and the evidence of the pervasiveness or severity of racial animus at the Academy is too isolated and too minimal to survive summary judgment. ${ }^{74}$

This suggests that the Court was unwilling to allow her intersectional claim to prevail, despite its awareness of intersectional theory, and the fact that an intersectional analysis would better capture her claim. The Fourth Circuit instead opted for the harder task of "parsing out her identities" which obscured the legitimacy of her race-based claim. In doing so, its ultimate ruling tragically minimizes the race-based enmity that compounded Tiffany's harassment, illustrating the existing gap between Tiffany's harms and Title VII intervention. ${ }^{75}$ The court's recognition of intersectionality, but reluctance to adopt an intersectional approach, unduly narrows the scope of Title VII protections.

In other cases, the Fourth Circuit has explicitly expressed its concerns regarding courts' ability to review race-plus claims. ${ }^{76}$ For instance, in a disparate treatment case on appeal, the court wrote,

We accept, for purposes of this appeal, the theoretical possibility of proving intentional racial discrimination on this narrow "race-plus" basis under circumstances conclusively shown to be free of any general racial bias in making comparable employment decisions. But we confess grave misgivings about the ability of courts fairly and rationally to assess the existence of such an amorphous special type of racial bias. ${ }^{77}$

Implicit in the Fourth Circuit's characterization of intersectional discrimination as "special" is a refusal or inability to grasp the amorphous nature of Title VII. Discrimination takes various forms and a broad interpretation of Title VII is needed to address the reality of how it occurs in contemporary workplaces. As discussed below, the language of Title VII permits Courts to assess discrimination, in various forms, including through an intersectional lens. ${ }^{78}$ Despite the remedial purpose of Title VII, the narrow approach taken by the Fourth and Eighth Circuits are incapable

\footnotetext{
${ }^{72} I d$. at 331

${ }^{73}$ Id. at $332-33$.

${ }^{74} \mathrm{Id}$. at $336-37$.

${ }^{75}$ See id.

${ }^{76}$ See, e.g., Miller v. Mercy Hosp., Inc., 720 F.2d 356, 363 n.9 (4th Cir. 1983); Leggett v. JW Aluminum Co., No. 2:09-0246-PMD-BM, 2009 WL 2885306 (D.S.C. Sept. 1, 2009).

${ }^{77}$ Miller, 720 F.2d at 363 n.9.

${ }^{78}$ Infra Parts IV(B)-(D).
} 
of fully addressing the full scope of harm that Black women workers face. ${ }^{79}$

Courts that take narrow approaches to Title VII race and sex discrimination claims made by Black women fail to see that the workplace discrimination they face is not one-dimensional. Requiring discrete claims for discrete categories should end across courts. It fails to protect Black women who experience discrimination and harassment and allows employers to evade Title VII liability based on an artificial construction of identity. In recognizing intersectional identities, courts will be able to address sex and race claims together as part of one singular claim rather than dissecting the discrimination and harassment to fit the traditional analytical frameworks.

\section{B. Sex-Plus Framework}

Increasingly, courts have broadened the interpretation of Title VII in a way that better accounts for Black women workers' intersectional identity and experiences in the workplace. One approach is to adopt a "sex-plus," and less commonly, a "race-plus" framework to analyze intersectional claims. ${ }^{80}$ For example, the Second, Third, and Tenth Circuits use different terms to describe the same sex-plus intersectional framework, interpreting Title VII to provide a remedy for discrimination because of multiple protected traits and related characteristics. ${ }^{81}$ The sex-plus framework was developed due to the inability of the traditional sex discrimination framework to fully encompass the various ways in which an employee may be discriminated against. This framework expands the notion of protected category by allowing plaintiffs to bring forth claims in which they allege discrimination based on multiple characteristics. ${ }^{82}$ Sex-plus discrimination is generally understood as a form of subgroup discrimination in which an employer targets only a certain segment of male or female employees due to the employee's sex and another characteristic, the "plus" characteristic. ${ }^{83}$ Thus, in a sex-plus discrimination claim, an employee alleges that they were discriminated against in part because of their sex, in addition to another characteristic they have, such as having young children or being married. ${ }^{84}$

The Supreme Court first established the sex-plus framework in its 1971 decision of Phillips $v$. Martin Marietta Corp. ${ }^{85}$ Originally, the sex-plus framework was used to carve out protections for employees who suffer discrimination based on sex, plus a neutral trait that is not protected under the statute. ${ }^{86}$ In Phillips, the female plaintiff, Ida Phillips, brought forth a Title VII sex discrimination action after being told by defendant, Martin Marietta Corporation, that it was not accepting applications from women with preschool aged children. ${ }^{87}$ At the time, Martin Marietta had employed men with preschool aged children and had also employed women without them.

${ }^{79}$ Miller, 720 F.2d at 363 n.10.

${ }^{80}$ Eric Bachman \& Karen Krims, What Is "Sex-Plus" Discrimination and Why Are these Employment Claims on the Rise?, NAT'L L. REV. (Aug. 5, 2020), <https://www.natlawreview.com/article/what-sex-plus-discrimination-andwhy-are-these-employment-claims-rise>.

${ }^{81}$ See Frappied v. Affinity Gaming Black Hawk, LLC, 966 F.3d 1038, 1048 (10th Cir. 2020).

${ }^{82} \mathrm{Id}$.

${ }^{83}$ Marc Chase McAllister, Proving Sex-Plus Discrimination Through Comparator Evidence, 50 SETON HALL. L. REV. 757, 760 (2020).

${ }^{84} \mathrm{Id}$. at 763 .

${ }^{85} \mathrm{Id}$. at 771.

${ }^{86}$ Pappoe, supra note 25 , at 19.

${ }^{87}$ Phillips v. Martin Marietta Corp., 400 U.S. 542, 543 (1971). 
Thus, the issue here was not that Phillips was being discriminated against solely because of her identity as a woman. Phillips was being discriminated against because of her sex plus the additional trait of her having preschool aged children. The Supreme Court recognized this when it held that a violation of Title VII occurs when an employer has a different hiring policy for men with children than it does for women with children. ${ }^{88}$ Since the Phillips decision, Circuit Courts have further developed the sex-plus employment discrimination framework, which can be applied to recognize intersectional claims brought by Black women.

For example, the Second Circuit adopted the sex-plus analytical framework to evaluate intersectional claims under Title VII. ${ }^{89}$ In Gorzynski v. JetBlue Airways Corp, the court allowed a claim where a plaintiff alleged she was being treated differently based on her status as an older woman. The court recognized that it was possible for an older woman employee to experience discrimination in such a way that not all members of her gender experience it, and in such a way that is different from what older male employees experience. ${ }^{90}$ In recognizing this, the Second Circuit held sex-plus-age claims actionable. ${ }^{91}$ Given the Second Circuit's receptiveness to intersectional claims that implicate other federal statutes, sex-plus race claims may fare well in this jurisdiction since these claims fall squarely within Title VII and do not implicate another federal law.

The Third Circuit also adopted the sex-plus framework when evaluating claims under Title VII. In Goosby v. Johnson \& Johnson Medical, Inc., a Black woman plaintiff brought forth a race and gender discrimination claim. ${ }^{92}$ There, the defendant attempted to argue that plaintiff's gender discrimination should be dismissed because the only other woman in plaintiff's division was reassigned to a more desirable position. ${ }^{93}$ However, the Third Circuit rejected the defendant's claim by noting that "evidence that [the employer] afforded a White female an assignment that it denied to a Black female hardly defeats a claim of race/gender discrimination brought by a Black female." "94 By noting this, the Third Circuit recognized that Black women experience sex discrimination in ways that white women do not. This acknowledgement effectively demonstrates that the Third Circuit recognizes intersectional claims.

Sex-plus doctrine continues to evolve as new Supreme Court decisions are handed down. In the recent Tenth Circuit case Frappied v. Affinity Gaming Black Hawk, LLC., the court relied on the Supreme Court's analysis in Bostock v. Clayton County to allow plaintiffs to proceed with a sex-plus-age disparate impact claim. ${ }^{95}$ In Bostock, the United States Supreme Court held that, when an employer makes an adverse employment decision in part because of the employee's

${ }^{88} I d$. at 544.

${ }^{89}$ See Gorzynski v. JetBlue Airways Corp., 596 F.3d 93, 109 (2d Cir. 2010) (“[A] plaintiff's discrimination claims may not be defeated on a motion for summary judgment based merely on the fact that certain members of a protected class are not subject to discrimination, while another subset is discriminated against based on a protected characteristic shared by both subsets.").

${ }^{90} I d$. at 110.

${ }^{91} I d$.

${ }^{92}$ Goosby v. Johnson \& Johnson Med., Inc., 288 F.3d 313 (3d Cir. 2000); see also Bryant v. Int'l Sch. Servs., Inc., 675 F.2d 562, 573 \& n.18 (3d Cir. 1982) (adopting the sex-plus framework for the Third Circuit).

${ }^{93}$ Goosby, 288 F.3d at 321.

${ }^{94} \mathrm{Id}$.

${ }^{95}$ Frappied v. Affinity Gaming Black Hawk, LLC, 966 F.3d 1038, 1045-48 (10th Cir. 2020) (discussing Bostock v. Clayton Cnty., 140 S. Ct. 1731 (2020)). 
identity as homosexual or transgender, the employer violates Title VII's prohibition on sex discrimination because the identities are interwoven. ${ }^{96}$ The plaintiffs in Frappied were casino workers who were laid off and alleged they were unlawfully discriminated against because they were women over forty years old. In the Frappied opinion, the court explicitly found that sex-plusrace claims to be valid and intersectional sex-plus-age discrimination to be prohibited by Title VII. ${ }^{97}$ Thus, the Tenth Circuit clarified that intersectional claims are also cognizable even if the plus trait, such as age or disability, falls within a separate statute. ${ }^{98}$ In this case, if the employer fires all older people, it is not because of sex, but if they are specifically terminating female older workers, but not male older workers, this is sex-plus discrimination prohibited by Title VII. ${ }^{99}$

In the Frappied opinion, the Tenth Circuit stressed the importance of recognizing intersectional claims. It reasoned that acknowledging these claims best reflects the congressional intent of Title VII, prohibiting discrimination based on stereotypes. ${ }^{100}$ Furthermore, it noted that when intersectional claims are not explicitly recognized, they are picked apart in such a way that paints an incomplete picture. ${ }^{101}$ The Tenth Circuit argued that when courts look at claims individually rather than recognizing how certain protected characteristics interact, they perpetuate a system which only views discrimination as a one-dimensional experience. ${ }^{102}$ Thus, those individuals with multiple protected Title VII characteristics, such as Black women, have their experiences reduced to traditional sex discrimination or race discrimination frameworks that are a misfit. Following the Frappied decision, it is possible that other circuits may also begin to see the importance of understanding intersectionality in the employment context. Further, plaintiffs and plaintiffs' attorneys may be more inclined to bring more nuanced claims as additional circuits begin to adopt sex-plus-race Title VII frameworks. ${ }^{103}$

The sex-plus framework is a step in the right direction by providing plaintiffs, attorneys, and courts an avenue to recognize intersectional claims involving two or more Title VII-protected categories. ${ }^{104}$ Specifically, for Black women employees, the sex-plus framework should serve as

\footnotetext{
96 Bostock v. Clayton Cnty., 140 S. Ct. 1731, 1742 (2020) (holding that an employer who fires an individual merely for being gay or transgender violates Title VII because "homosexuality and transgender status are inextricably bound up with sex.").

97 See Frappied, 966 F.3d at 1045 ("Title VII also prohibits discrimination based on a combination of protected characteristics, such as 'sex-plus-race' discrimination, i.e., discrimination targeted only at employees of a particular race and sex. See Connecticut v. Teal, 457 U.S. 440, 455 (1982) ('It is clear that Congress never intended to give an employer license to discriminate against some employees on the basis of race or sex merely because he favorably treats other members of the employees' group.'); see also Hicks v. Gates Rubber Co., 833 F.2d 1406, 1416-17 (10th Cir. 1987) (same).").

98 Id. at 1048-49; Age Discrimination in Employment Act of 1967, 29 U.S.C. $\$ \S 621-34$ (ADEA); Americans with Disabilities Act of 1990, 42 U.S.C. $\S \S 12101-12213$.

99 Frappied, 966 F.3d at 1047 ("This affirms our ruling in Coleman that a female sex-plus plaintiff must show that her employer treated her unfavorably relative to a male employee who also shares the 'plus-' characteristic.”). In Frappied, the Tenth circuit also followed Bostock and lessened the burden of proof on female intersectional plaintiffs. Id. at 1050-51.

${ }^{100} \mathrm{Id}$. at $1048-49$.

$101 \mathrm{Id}$. at 1048 .

${ }^{102} \mathrm{Id}$.

${ }^{103}$ Bachman \& Krims, supra note 79.

${ }^{104} I d$.
} 
a non-controversial mechanism for bringing forth the intersectional sex-plus-race discrimination claim, given these identities are both protected under Title VII. The sex-plus framework further forces courts to face the reality that some sex discrimination claims are more complex than others. Again, in the case of the Black woman employee, many times, the discrimination faced by Black women differs from that faced by Black men and white women. ${ }^{105}$

While recognizing intersectional claims under the sex-plus framework is an improvement over analyzing the claims separately, there are drawbacks to this approach. First, sex discrimination is still the heart of the claim which de-centers racial identity and experiences. ${ }^{106}$ Therefore, this doctrine still requires Black women to bisect their identity and choose sex as the primary trait if they want to pursue a claim in a sex-plus jurisdiction. This framing makes Black women hold their race out as secondary, which minimizes that part of their identity and the racial component of the discrimination experienced, which also encourages the courts to treat it as such. ${ }^{107} \mathrm{~A}$ true intersectional approach would not relegate a characteristic, such as race, as subordinate and less central than the sex characteristic. Instead, a true intersectional claim would recognize that both characteristics are central to the analysis, making the claim more than just a variant of sex discrimination. ${ }^{108}$

Second, some circuits that recognize sex-plus as a legitimate framework have not similarly acknowledged race-plus as a viable claim. ${ }^{109}$ At a minimum, courts should be recognizing both sex-plus claims and race-plus claims. For example, a Black woman plaintiff could bring a raceplus-sex discrimination claim where she compares her employer's actions towards her to the employer's actions toward her white female coworkers. This framework is needed so that Black women plaintiffs have an opportunity to bring intersectional race discrimination claims and not just intersectional sex discrimination claims. Ideally, courts should move beyond the "plus" framing, to combine the race and sex claims in such a way that places both at the heart of the claim.

Lastly, both sex-plus and race-plus discrimination claims overemphasize comparator analysis. ${ }^{110}$ In Coleman, the Tenth Circuit held that "gender-plus plaintiffs can never be successful if there is no corresponding subclass of members of the opposite gender" because, without a comparator, those plaintiffs will be unable to show they were treated differently from those who

105 See, e.g., Jenkins v. Blue Cross Mut. Ins., Inc., 538 F.2d 164, 167 (7th Cir. 1976) (Black woman denied a promotion by her supervisor because she "could never represent Blue Cross with [an] Afro").

106 Pappoe, supra note 25, at 16.

${ }^{107} \mathrm{Id}$.

108 See Kate Sablosky Elengold, Clustered Bias, 96 N.C. L. REV. 457, 498 (2018) (explaining that intersectional identity is not an additive experience and that intersectional discrimination cannot be broken apart into two truly distinct claims).

109 The Second, Third, and Tenth Circuits all recognize some variant of the sex-plus framework, but have not adopted a race-plus framework, though some district courts within these circuits have evaluated or discussed it. See Craig v. Yale Univ., 838 F. Supp. 2d 4, 8-9 (D. Conn. 2011) (finding that allegations were sufficient to state intersectional claim of race-plus-gender discrimination, but not solely gender); Sharpe v. MCI Commc'ns Servs. Inc., 684 F. Supp. 2d 394, 405 (S.D.N.Y. 2010) (stating that the Second Circuit has explicitly not adopted the race-plus framework); Fattaey v. Kansas State Univ., No. 15-9314-JAR-KGG, 2017 WL 2264359, at *6 (D. Kan. May 24, 2017) (acknowledging that the EEOC manual expressly incorporates race-plus claims into Title VII prohibitions); Murray v. Se. Pa. Transit Auth., No. CIV. A. 96-7971, 1998 WL 98987, at *4 n.4 (E.D. Pa. Mar. 9, 1998) (noting that the plaintiff had not asserted a claim for gender or "race plus gender" discrimination).

${ }^{110}$ McAllister, supra note 82 , at 796. 
are similarly situated. ${ }^{111}$ Thus, a Black woman bringing a sex plus race discrimination claims, must center the argument on comparing her treatment to the treatment of Black male employees. ${ }^{112}$ For race-plus-sex claims, courts require a comparison of Black women employees to their white women counterparts. Some scholars have noted that this focus on comparator analysis is both overinclusive and underinclusive. ${ }^{113}$ Overinclusive in that it does not prove as much as it is believed to prove and underinclusive in that a comparator's absence does not mean that discrimination has not occurred. ${ }^{114}$ Following Coleman, lower courts applying sex-plus framework to Title VII claims tend to treat comparator analysis as a threshold requirement for proving that discrimination actually occurred. ${ }^{115}$ These courts that have followed the Tenth Circuit's decision in Coleman should recognize that comparator analysis is no longer required by the Tenth Circuit following Frappied.

\section{Black Women as a Protected Class}

The Fifth and Eleventh Circuits have considered race and sex claims together and held that Black women are a protected class. ${ }^{116}$ The Fifth Circuit was the first circuit to recognize protection specific to Black women. In the seminal case, Jefferies $v$. Harris County (discussed above), the Court found that Black women were protected under Title VII as a sub-group given "their race and sex because to deny their unique experiences would leave them without a viable Title VII remedy." 117 Using this framework, in Williams v. City of Tupelo, Mississippi, the Fifth Circuit analyzed a Title VII claim from a Black female police officer cadet who alleged discrimination on the basis of her race and sex. ${ }^{118}$ The plaintiff alleged that she had applied to become a police officer

${ }^{111}$ Coleman v. B-G Maint. Mgmt. of Colo., Inc., 108 F.3d 1199, 1204 (10th Cir. 1997).

112 Frappied v. Affinity Gaming Black Hawk, LLC, 966 F.3d 1038, 1047 (10th Cir. 2020) (holding that a female sex-plus plaintiff need not "prove that the subclass of women" to which she belongs "was unfavorably treated as compared to the corresponding subclass of men." She just needs to prove that she would not be terminated but for her sex. The court allowed the disparate impact claim to proceed and held that sex discrimination occurs when older women are discriminated against, even if the same is not happening to older members of the other sex, or every older woman).

${ }^{113}$ Suzanne B. Goldberg, Discrimination by Comparison, 120 YALE L. J. 728 (2011).

${ }^{114} \mathrm{Id}$. at 772 (arguing that "comparatively different treatment revealed by the heuristic [comparator analysis] is a byproduct of discrimination rather than the discrimination itself").

115 Id.; see Frederick v. New Hampshire, No. 14-CV-403-SM, 2016 WL 4382692, at *9-10 (D.N.H. Aug. 16, 2016) (holding that plaintiff failed to allege that her subclass of women was unfavorably treated as compared to a corresponding subclass of men); see also Rafalski v. Donahoe, No. 10-CV-40060-TSH, 2012 WL 4753274, at *8 (D. Mass. Oct. 3, 2012) (holding that plaintiff's gender-plus-married claim failed because the only comparator was her husband who had also been affected by employer's decision to change her vacation schedule).

116 See Shazor v. Pro. Transit Mgmt., 744 F.3d 948, 958 (6th Cir. 2014) (“African American women are subjected to unique stereotypes that neither African American men nor white women must endure.”); Lam v. Univ. of Haw., 40 F.3d 1551, 1562 (9th Cir. 1994) ("[W]here two bases for discrimination exist, they cannot be neatly reduced to distinct components.").

${ }^{117}$ Pappoe, supra note 25, at 3 (citing Jefferies v. Harris Cnty. Cmty. Action Ass'n, 615 F.2d 1025, 1032 (5th Cir. 1980)); see Jefferies v. Harris Cnty. Cmty. Action Ass'n, 615 F.2d 1025, 1034 (5th Cir. 1980) (“[W]hen a Title VII plaintiff alleges that an employer discriminates against black females, the fact that black males and white females are not subject to discrimination is irrelevant and must not form any part of the basis for a finding that the employer did not discriminate against the black female plaintiff.").

118 Williams v. City of Tupelo, 414 F. App'x 689, 694 (5th Cir. 2011). 
and was dismissed and subsequently replaced by a white male because she was a Black woman. ${ }^{119}$ The district court initially granted summary judgment for the City, finding that they had hired a number of Black men and that the plaintiff had not sufficiently passed firearms training. ${ }^{120}$ The Fifth Circuit reversed, finding that there were genuine issues of material fact as to whether the plaintiff had sufficiently passed training, and ample evidence to suggest that the "real reason" her supervisors recommended her dismissal was that they did not want a Black woman working with them. ${ }^{121}$ Relying on Jefferies, the Court noted that it was irrelevant that the city had hired Black men and white women, since it had failed to hire a Black woman since 2004. ${ }^{122}$

The Eleventh Circuit has also recognized Black women as a distinct protected subgroup under Title VII. ${ }^{123}$ In Mosley v. Alabama Unified Judicial System, a Black juvenile probation officer brought an action under Title VII alleging that she was discriminated against based on her sex and race. On appeal, the Eleventh Circuit affirmed the district court's summary judgment decision to limit Mosley's Title VII discrimination claims to those of only gender discrimination. The Eleventh Circuit reasoned that Mosley had identified the Title VII discrimination claim in her summary judgment brief as a "sex discrimination claim," and, while she satisfied her prima facie case because she was an "African American female," she had not provided any other reference to the distinct protected subclass of Black woman or citations to case law regarding "intersectional discrimination." 124 Following the Mosley precedent, a Black woman plaintiff would need to plead race and sex discrimination based on her protected class as a Black woman, citing to related case law analyzing intersectional discrimination.

While these circuits have at least acknowledged the identities of Black women and their experiences in the workplace, this approach may face similar limitations as other courts who employ the traditional sex-plus framework. While Jefferies acknowledged that Black women are entitled to a viable remedy under Title VII as a protected sub-group, the court still used "sex" as the main method of analysis, inferring that the plaintiff's race as a Black woman was a secondary characteristic that should be analyzed only "in addition" to her sex claim, thereby subordinating her racial identity. ${ }^{125}$

\section{Totality or Aggregate Framework}

The Sixth and Ninth Circuits have not explicitly categorized Black women as a protected class, but they do consider Title VII intersectional race and sex claims together under an "aggregate" or

119 Id.

${ }^{120} I d$. at 693.

${ }^{121} \mathrm{Id}$. at 694 .

${ }^{122} \mathrm{Id}$.

${ }^{123}$ Mosley v. Ala. Unified Judicial Sys., 562 F. App’x 862, 867 (11th Cir. 2014) (recognizing black females as a distinct protected subgroup under Title VII). In Bonner v. City of Prichard, 661 F.2d 1206, 1209 (11th Cir. 1981) (en banc), the Eleventh Circuit adopted as binding precedent all decisions of the former Fifth Circuit handed down prior to close of business on September 30, 1981.

124 See Harrington v. Cleburne Cnty. Bd. of Educ., 251 F.3d 935, 937 (11th Cir. 2001) (defining "intersectional" discrimination as a situation where "the defendant treated [the plaintiff] disparately because she belongs simultaneously to two or more protected classes").

125 Jefferies v. Harris Cnty. Cmty. Action Ass'n, 615 F.2d 1025, 1033-34 (5th Cir. 1980); Powell, supra note 62, at 421-22; Cathy Scarborough, Conceptualizing Black Women's Employment Experiences, 98 YALE L. J. 1457, 147071(1989); Areheart, supra note 25, at 220. 
"totality" framework. ${ }^{126}$ In Lam v. University of Hawaii, the Ninth Circuit evaluated a discrimination claim from a Vietnamese woman who applied for and was denied a university professor position. She filed suit alleging the University discriminated against her during the hiring process based on her race, sex, and national origin. The district court granted summary judgment to the University, in part, because the University favorably considered an Asian man and white woman as candidates for the position. The Ninth Circuit, citing Kimberlé Crenshaw, criticized the district court's treatment of Lam's claims as mathematical and determined that two or three bases of discrimination "cannot be neatly reduced to distinct components." ${ }^{127}$ Instead, the court held that it is necessary for courts to consider a plaintiff's claim of discrimination based on a combination of two or more protected categories rather than focus solely on whether an employer discriminates based on one category or another. ${ }^{128}$ The Sixth Circuit adopted the Lam court's rationale in Shazor v. Professional Transit Management, specifying that Title VII is meant to protect plaintiffs who "fall between two stools" when claims involve multiple protected characteristics. ${ }^{129}$ The Court reasoned that the "realities of the workplace" prohibit an "artificial approach" to Title VII claims where protected characteristics are treated separately. ${ }^{130}$

Both the Tenth and Third Circuits have shown signs of analyzing beyond just sex-plus and adopting the broader "totality" approach to analyze intersectional claims like the Sixth and Ninth circuits. The Tenth Circuit went in this direction in Hicks v. Gates Rubber Company, where a Black female security guard brought a Title VII action against her former employer for harassment based on race and sex. ${ }^{131}$ After a bench trial, the district court rejected Hicks' claims of a racially hostile work environment, along with a separate sex based hostile work environment claim. ${ }^{132}$ On appeal, while the Tenth Circuit affirmed the district court's findings for Hicks' race hostile work environment claim, the Court remanded Hicks' sex harassment claim. Hicks introduced evidence that her supervisor made serious racial slurs, and the Court found that those incidents of racial harassment were insufficient to support a racially hostile work environment claim but could be combined with incidents of sexual harassment to prove a pervasive pattern of discriminatory harassment in violation of Title VII. Similarly, in Goosby, the Third Circuit alluded to the totality approach for disparate treatment claims by framing the plaintiffs claim as "race/gender

${ }^{126}$ See Shazor v. Pro. Transit Mgmt., 744 F.3d 948, $957-58$ (6th Cir. 2015); Lam v. Univ. of Haw., 40 F.3d 1551, 1561-62 (9th Cir. 1994).

${ }^{127}$ Lam, 40 F.3d at 1562 n.20.

${ }^{128}$ Id. at 1561-62; see also Anthony v. Cnty. of Sacramento, 898 F. Supp 1435, 1445 (E.D. Ca 1995) ("The Ninth Circuit now recognizes combined race and sex discrimination claims under Title VII. Where a woman of color alleges that she has been subject to discrimination on the combined bases of her race and gender, it is error for the court to analyze sex and race separately. Rather, the proper inquiry is whether the employer discriminated on the basis of the combined factors.") (internal citations omitted).

${ }^{129}$ Shazor, 744 F.3d at 958. The Supreme Court has also made a passing reference to discrimination unique to Black women. See Olmstead v. L.C., 527 U.S. 581, 598 n.10 (1999) (citing Jefferies, 615 F.2d at 1032) ("Discrimination against black females can exist even in the absence of discrimination against black men or white women.").

${ }^{130}$ Shazor, 744 F.3d at 958; see also Wade v. Automation Pers. Serv., 612 F. App’x 291, 299-300 (6th Cir. 2015) (referring to the Sixth Circuit's approach as the "cumulative theory of harassment").

${ }^{131}$ Hicks v. Gates Rubber Co., 833 F.2d 1406, 1416-17 (10th Cir. 1987).

${ }^{132} I d$. 
discrimination." 133 Unlike sex plus, in Goosby, the Third Circuit was not placing one trait as superior to the other; instead, it recognized that both traits played an equal role in the adverse employment action.

While the "aggregate" or "totality" framework appears to better analyze intersectional claims, like those circuits identifying Black woman as a protected category, or those using sex-plus, courts using the totality approach have continued to place an analytical emphasis on "sex." In Hicks, despite the fact that the defendant conceded that "racial slurs and jokes were tolerated" in the workplace, the Tenth Circuit concluded that a few "casual comments" were insufficient for a racially hostile work environment, even though the plaintiff was the only Black woman in her security force and there were only two Black guards. ${ }^{134}$ Yet, while analyzing her sex claim, the Court had no issue with "aggregat[ing] evidence of racial hostility with [her] evidence of sexual hostility."135

This approach may also present disadvantages when bringing disparate impact claims, depending on how the court analyzes the claim. In Moore v. Hughes Helicopter, the Ninth Circuit affirmed the rejection of a plaintiff's class action certification seeking to represent Black women, Black men, and white women in a disparate impact action. ${ }^{136}$ The district court had certified a class of Black female employees but would not allow the plaintiff to represent White women because the plaintiff claimed that she was discriminated against as a Black woman, not as a woman in general. ${ }^{137}$ As a result, the plaintiff was only able to use statistical evidence showing "aggregate" disparate impacts against Black women specifically, even though there was other evidence suggesting that the employer's practices also had a disparate impact on all Black employees and all women. ${ }^{138}$ The Ninth Circuit ultimately affirmed the district court's determination that the plaintiff could not create a prima facie case of disparate impact. ${ }^{139}$

\section{E. Additional Approaches}

The Supreme Court, First Circuit, and D.C. Circuit have not specifically addressed how intersectional claims fit under Title VII or take inconsistent approaches to this issue. The First Circuit inconsistently handles the Title VII cases, using sex-plus theory in some cases but not others. ${ }^{140}$ In Hicks $v$. Johnson, a Black female plaintiff alleged race and gender discrimination for failure to promote, where a white male was promoted instead. ${ }^{141}$ The Plaintiff had twenty years of government service, a majority of which was in the department in which she sought a promotion. ${ }^{142}$ When the manager retired, she and a white man with less than two years of experience in the office

${ }^{133}$ Goosby v. Johnson \& Johnson Med., Inc., 228 F.3d 313, 321 (3d Cir. 2000).

${ }^{134}$ Hicks, 833 F.2d at 1416-17.

${ }^{135} \mathrm{Id}$.

${ }^{136}$ Moore v. Hughes Helicopters, Inc., 708 F.2d 475, 480 (9th Cir. 1983).

${ }^{137} \mathrm{Id}$.

${ }^{138} I d$. at 484 .

${ }^{139} I d$. at 486.

${ }^{140}$ Compare Franchina v. City of Providence, 881 F.3d 32, 54 (1st Cir. 2018) (sex-plus claims do not require a higher standard than traditional Title VII discrimination claims) with Hicks v. Johnson, 755 F.3d 738, 744 n.6 (1st Cir. 2014) (Black woman brought claim of race and gender discrimination for failure to promote, but the court focused on the race discrimination claim).

${ }^{141}$ Hicks v. Johnson, 755 F.3d at 742.

${ }^{142} I d$. at 741. 
were listed as the top two candidates for promotion based on eligibility for the position. ${ }^{143}$ Both were interviewed by a panel following the same questions and a numerical rubric, which rendered a "split decision," but the white male with less experience was promoted. ${ }^{144}$ She filed claims that the failure to promote was based on her race and gender and the district court granted defendants summary judgment. ${ }^{145}$ The First Circuit noted that the plaintiff filed claims for race and sex as a Black woman, but offered statistics that focused on the underrepresentation of Blacks in management, not Black women. ${ }^{146}$ The court also noted that the department generally promoted white women, so the claim of race and gender discrimination must fail. ${ }^{147}$

The D.C. Circuit has not officially adopted any analytical framework to evaluate intersectional claims under Title VII. Judge v. Marsh is a notable D.C. District Court case that applied sex-plus, but reluctantly and criticized the approach as being overly broad and turning employment discrimination into a "many-headed hydra" that would allow claims based on too many combinations of protected categories. ${ }^{148}$ In a more recent D.C. District Court case, Allen $v$. Mnuchin, a Black woman filed a complaint against her employer for race and sex discrimination dating back to $2008 .{ }^{149}$ In the complaint, she alleged several violent incidents of racism with a white male co-worker. ${ }^{150}$ In response to her complaint, her employer, the U.S. Department of Treasury, filed a motion to dismiss her various claims, specifically noting that her race and sex claims were duplicative. ${ }^{151}$ Ms. Allen's disparate treatment claim survived the motion to dismiss and is still pending. ${ }^{152}$ However, the district court's analysis demonstrates a harmful flaw in the court's approach to intersectional claims. ${ }^{153}$ The court cautioned Ms. Allen to "more crisply differentiate her claim for race-based discrimination from her claim for sex/gender-based discrimination to clarify how each of her factual allegations connects to each of [her] distinct theories of hostile work environment discrimination." "154 As a result, the district court created unnecessary tension and barriers to Ms. Allen's claim, which was intersectional by nature and predicated on her full identity as a Black woman employee. ${ }^{155}$

143 Id.

${ }^{144}$ Id. at 742 .

${ }^{145} I d$. at $742-43$.

${ }^{146}$ Id. at 747.

${ }^{147}$ Id. at 744 n.6.

148 Judge v Marsh, 649 F. Supp. 770,780 (D.D.C. 1986).

149 Allen v. Mnuchin, No. 18-1214 (RC), 2019 WL 2581323 (D.D.C. June 24, 2019).

${ }^{150}$ Id. at *2-4. Ms. Allen's encounters with Mr. Wilson began in 2008 when he kicked a trash can at Ms. Allen's head while yelling at her, seemingly unprovoked. Id. at *2. This initial interaction was followed by numerous incidents of verbal abuse and intimidation. Although they were directed to refrain from communicating and interacting, Ms. Allen also alleged other incidents where Mr. Wilson hit her on the head with his cane, angrily harassed Ms. Allen and other Black female employees, and searched KKK websites on his work computer. Her encounters with her white male co-worker continued to go unaddressed. $I d$. at *2-4. Ultimately, the lack of discipline from supervisors, who received multiple reports about Mr. Wilson's harmful behavior and racist actions, forced Ms. Allen to file an EEO complaint and eventually a federal lawsuit against her employer. $I d$. at *5.

${ }^{151}$ Id. at $* 10$.

152 Id. at $* 11$.

${ }^{153} \mathrm{Id}$.

${ }^{154}$ Id. at $* 10$.

${ }^{155}$ Id. 
Table 1. Approaches to Analyzing the Intersectional Claims of Black Women: A Survey of the United States Courts of Appeals

\begin{tabular}{|l|l|}
\hline \multicolumn{1}{|c|}{ Approach to Intersectional Claims } & Court of Appeals \\
\hline Protected Traits Analyzed Separately & Fourth, Eighth \\
\hline $\begin{array}{l}\text { Recognizes Intersectional Claims } \\
\text { Sex-Plus Race and/or Race-Plus Sex }\end{array}$ & Second, Third, Tenth \\
\hline $\begin{array}{l}\text { Recognizes Intersectional Claims } \\
\text { Black Woman = Protected Category }\end{array}$ & Fifth, Eleventh \\
\hline $\begin{array}{l}\text { Recognizes Intersectional Claims } \\
\text { "Aggregate" or "Totality" Framework }\end{array}$ & Sixth, Ninth \\
\hline Inconsistent/Undecided & First, D.C. \\
\hline
\end{tabular}

\section{EMERGING STRATEGIES FOR ADDRESSING BLACK WOMEN’S INTERSECTIONAL CLAIMS}

New developments in the courts and in employment policy over the past several years may further influence how discrimination and harassment claims brought by Black women are analyzed. This includes: (1) Justice Gorsuch's opinion in the Supreme Court case Bostock $v$. Clayton County; (2) "discriminatory harassment" framing in recent state antidiscrimination reform; and (3) the prospect of a reasonable black women standard for assessing claims.

\section{A. What Bostock v. Clayton County Means for Black Women}

The United States Supreme Court has not decided an intersectional sex and race Title VII claim. However, the 2019 case Bostock v. Clayton County may have implications for Black women plaintiffs. ${ }^{156}$ In Bostock, the Supreme Court found that an employer violates Title VII's prohibition on sex-based employment discrimination when firing an employee for being homosexual or being transgender. ${ }^{157}$ Conservative Justice Neil Gorsuch, appointed by former President Trump wrote the majority opinion and was joined in full by fellow conservative Chief Justice Roberts. Gorsuch made three main arguments which could impact the intersectional claims brought by Black women. First, Gorsuch argued that it is impossible to discriminate against an employee for being

156 Bostock v. Clayton Cnty., 140 S. Ct. 1731, 1737 (2020).

${ }^{157} \mathrm{Id}$. 
homosexual or transgender without discriminating against that employee based on sex. ${ }^{158}$ Second, he reiterated that discriminatory employment decisions are "because of sex" even if an employer only relies "in part on an individual employee's sex." "159 Finally, he reaffirmed that an employer may discriminate against individual employees while not discriminating against everyone in their group. ${ }^{160}$

The language used in the Bostock opinion can reasonably be understood to support intersectional claims under Title VII. When Gorsuch argues that it is impossible to discriminate against a person for being homosexual or transgender without a consideration of sex, he notes that gay and transgender identities are inextricably linked to one's sex. Based on this interpretation, it impossible for an employer to argue that discriminating against an employee because they are homosexual or transgender is not also sex-based discrimination. ${ }^{161}$ Gorsuch recognizes that some characteristics are so intertwined with a plaintiff's Title VII protected traits that they cannot be thought of as separate. It may follow then, for Black women alleging sex and race discrimination, that it is impossible to discriminate against her without being discriminatory of both her race and her sex, which are inextricably linked. ${ }^{162}$ Discrimination based on sex and race also do not occur in "separate spheres" for Black women. ${ }^{163}$ For Black women, one cannot adequately analyze and remedy one form of subordination - e.g. sex - in the absence of examining how interrelated systems of domination - e.g. race - also shape the outcome. ${ }^{164}$ Accordingly, discrimination based on one's identity as a Black woman necessarily entails discrimination based both on her sex and her race. ${ }^{165}$

Additionally, Gorsuch recognizes that sex need not be the only factor involved for a plaintiff to make out a successful Title VII sex discrimination claim. He clarified the statute by holding that "an employer violates Title VII when it intentionally fires an individual based in part on sex." 166 Furthermore, Gorsuch noted that "it makes no difference if other factors besides the plaintiff's sex contributed to that decision ...." "167 This clarifies that if plaintiffs can prove that multiple protected traits combine as "but-for" causes of the adverse action, they should prevail. ${ }^{168}$ This language impacts Black women with intersectional race and sex claims because these plaintiffs will no longer have to make a choice and argue that the discriminatory action occurred solely because of race or sex. At a minimum, we now know that when multiple traits play a part in Black women's

${ }^{158} I d$. at 1742 .

${ }^{159} \mathrm{Id}$. at 1741 .

${ }^{160} \mathrm{Id}$. at 1743 .

${ }^{161} \mathrm{Id}$.

162 See generally Patricia Hill Collins, African Americans, Gender, and the New Racism (2004) (analyzing how racism, sexism, and class oppression rely on heterosexism to mutually construct social identities that foster Black subordination).

${ }^{163}$ Darren L. Hutchinson, Identity Crisis: "Intersectionality," "Multidimensionality," and the Development of an Adequate Theory of Subordination, 6 MicH. J. RACE \& L. 285, 289 (2001).

${ }^{164} I d$. at 315-16.

${ }^{165}$ Bostock, 140 S. Ct. at 1747.

${ }^{166} \mathrm{Id}$. at 1741 .

${ }^{167} I d$.

${ }^{168}$ Id. at 1739 (asserting that but for causation is a "sweeping standard" and that the protected characteristic does not have to be the "primary" cause of the decision for liability to attach); Ann C. McGinley, Feminist Perspectives on Bostock v. Clay County, Georgia, 53 ConN. Law Rev. 1, 4-5 (2020). 
sex discrimination claims, this does not diminish the fact that there was a Title VII violation.

Lastly, in Bostock, the Supreme Court reaffirmed that "a rule that appears evenhanded at the group level can prove discriminatory at the level of individuals." 169 The Court reasoned that an employer's motivation to achieve class wide equality between the sexes does not justify individual discrimination on the basis of sex. ${ }^{170}$ Clayton County violated Title VII because, "it could not 'pass the simple test' asking whether an individual female employee would have been treated the same regardless of her sex." ${ }^{171}$ Although this reading of Title VII does not address intersectionality directly, it suggests that a rule that does not exclude women, Black employees, or even Black women as a whole, can still be found to discriminate against an individual Black woman.

The way in which circuit courts interpret Bostock will surely influence Title VII claims brought by Black women. As discussed in Part IV, in Frappied the Tenth Circuit interpreted Bostock to hold that sex discrimination occurs when an employer treats employees with the same "plus" characteristic differently. ${ }^{172}$ The Frappied decision effectively demonstrates "how much of a Boon Bostock was for intersectional conceptions of discrimination." 173 In the case of Black women plaintiffs alleging combined sex and race discrimination, the Tenth Circuit followed Bostock to find that sex discrimination occurred if an employer treated Black men differently than they treat Black women. At a minimum, other circuit courts may follow this approach, allowing Black women to bring similar sex-plus-race claims. However, this approach remains limited, as it does not fully capture the various ways Black women may experience discrimination, with their sex not being dominant over race; race-plus (discrimination compared to white women); or intersectional harassment.

\section{B. State Law "Discriminatory Harassment” Framing}

While Title VII is intended to protect employees from discrimination, including harassment, the statute does not define what constitutes workplace harassment. ${ }^{174}$ Thus, harassment law has been left to the interpretation of the courts, and the tests, standards, and evidence requirements

\footnotetext{
${ }^{169}$ Bostock, 140 S. Ct. at 1743; see also Connecticut v. Teal, 457 U.S. 440, 442 (1982) (rejecting employers "bottom line" defense where employer justified discrimination against the Black plaintiffs on the basis favorable treatment of other members of these respondents' racial group).

${ }^{170}$ Bostock, 140 S. Ct at 1743; see also Ricci v. DeStefano, 557 U.S. 557, 581-84 (2009) (holding, in a case brought by white firefighters, that employers' motivation to reduce group level racial disparities did not justify discrimination against individual white firefighters). But see Johnson v. Transp. Agency, 480 U.S. 616, 637-38 (1987) (holding that an employee's sex can be taken into account as one factor in determining that she should be promoted, if the employer has a valid affirmative action plan that represents a moderate, flexible, case-by-case approach to effecting a gradual improvement in the representation of minorities and women).

${ }^{171}$ Bostock, 140 S. Ct. at 1743 (citations omitted).

${ }^{172}$ Frappied v. Affinity Gaming Black Hawk, LLC, 966 F.3d 1038, 1048 (10th Cir. 2020).

173 Timon Cline, Intersectionality Goes to Court, NEW Discourses (Jan. 5, 2021), <https://newdiscourses.com/2021/01/intersectionality-goes-to-court>.

${ }^{174}$ Section 703 of the Civil Rights Act of 1964, provides in relevant part:

(a) Employer practices

It shall be an unlawful employment practice for an employer-(1) to fail or refuse to hire or to discharge any individual, or otherwise to discriminate against any individual with respect to his compensation, terms, conditions, or privileges of employment, because of such individual's race, color, religion, sex, or national origin ....

42 U.S.C. $\S 2000 \mathrm{e}-2$.
} 
vary widely. Given continued federal inaction, state legislators are leading the way in antidiscrimination and harassment reform efforts. ${ }^{175}$ For example, in 2019, New York passed a law that replaced "sexual harassment" with a broader "discriminatory harassment" framework for the New York equivalent of Title VII. ${ }^{176}$ The hope is that the discriminatory harassment framing will better protect individuals with intersectional claims based on multiple protected classes, not just those experiencing discrimination and/or harassment based on sex. Unlike New York, most state-led harassment reforms, both proposed and passed in recent years, only offer stronger protection for sex harassment claims, but not for race, religious, and other types of prohibited harassment. ${ }^{177}$

While these reforms are a step in the right direction, they are not sufficient to enact real change in the lives of the many Black women and other women of color who often experience discrimination and harassment based on their sex and race, or other core identities. For example, in many of the states have considered laws that address mandatory arbitration and nondisclosure agreements. ${ }^{178}$ However, the legislation only places limits on mandatory arbitration and nondisclosure agreements for claims of sexual harassment or assault. As a result, those experiencing intersectional harassment or discrimination based on other protected characteristics, including race, ethnicity, or national origin, will continue to be vulnerable to these types of agreements.

Although state and federal legislatures should continue to pursue reforms, new laws will do little to stop harassment against Black women without broad recognition of entrenched racial and economic disparities in the legal system and society more broadly. Judges hearing these cases must better understand how those structural disparities serve to legitimate existing maldistributions of wealth and power, and shape workplace experiences for Black women. As such, it is of the utmost importance to not only elect Black women to the legislature, but also to elect and appoint them as state and federal judges, who may be more likely to prioritize these unique structural issues faced by Black women and other women of color.

Some lawmakers may push back against the discriminatory harassment approach, fearing that eliminating the use of the words "sexual harassment" from proposed state laws may diverge from what constituents want: reform that specifically tackles harassment and misconduct that is sex or gender specific, even if using a broader definition of harassment would protect more women. ${ }^{179}$ This fear reflects a fundamental misunderstanding of harassment claims that infects the analysis of circuit courts, i.e. focusing solely on claims related to sex versus other protected traits when the female plaintiff also has a marginalized racial identity. ${ }^{180}$ As noted above, a doctrinal framework based on a "because of sex" analysis fails to address the reality of multidimensional discrimination and harassment, such as racialized sex harassment. In addition to focusing solely on sex

175 Infra Part VI.

${ }^{176}$ A. 8421, § 13, Assemb. 2019-2020 Reg. Sess. (N.Y. 2019).

177 Infra Part VI.

${ }^{178}$ Forced arbitration of Title VII and state law harassment claims is particularly problematic for Black women, who are disproportionately subject to these agreements due to their high representation in low wage jobs, and often unequal bargaining power when entering these agreements.

${ }^{179}$ See generally Donald L. Revell \& Jessica Vapnek, Gender Silent Drafting in a Non-Binary World, 48 CAPITAL UNIV. L. REV. 103 (2020).

${ }^{180}$ See supra Part IV. 
harassment law, the discriminatory harassment framework makes room for intersectional theory to help address gaps in protection in a range of other contexts, such as racialized religious harassment, racialized disability harassment, and gender-based age harassment.

Ultimately, even reform efforts targeting a broader range of workplace harassment will only partially resolve the obstacles facing Title VII plaintiffs. As discussed in Part III, courts have a separate and distinct analysis for Title VII disparate treatment, ${ }^{181}$ disparate impact, ${ }^{182}$ hostile work environment, ${ }^{183}$ and retaliation claims. ${ }^{184}$ Black women often face discrimination across these causes of action, not just siloed harassment. Parceling an individual plaintiff's experience into these discrete incidents, subject to separate tests with varying burdens of proof, ultimately undermines the law's intent and the text of Title VII itself. The text of the statute explicitly states that its fundamental purpose is to make it unlawful for an employer to "discriminate against any individual with respect to his compensation, terms, conditions, or privileges of employment" on the basis of protected traits. ${ }^{185}$ A more unified approach, tackling the discrimination, harassment, and retaliation an individual experiences together, may remove some of the arbitrary barriers put in place by courts and more realistically approach workplace claims, where one's identity and experiences are not so easily separated.

\section{Reasonable Black Woman Standard}

Courts are increasingly deciding issues like the fact-intensive severe or pervasive standard for hostile environment claims at the summary judgment stage. ${ }^{186}$ The court must review the facts and hold whether the challenged discriminatory conduct is both subjectively and objectively severe or pervasive enough to create a hostile work environment. If the judge assesses that it is not, the claim will be defeated at summary judgment before having an opportunity to proceed to a jury of peers.

${ }^{181}$ An employee who makes a disparate treatment claim alleges that he or she was treated differently than other employees who were similarly situated and that the difference was based on a protected characteristic. Almost all of the circuits use the "adverse employment action" test to analyze whether a plaintiff was subject to disparate treatment. This test considers only whether Defendants' conduct constituted an "adverse employment action," which has been inconsistently defined in the circuits. Compare Thompson v. City of Waco, 764 F.3d 500, 503-04 (5th Cir. 2014) (defining adverse employment action only as "ultimate employment decisions," such as "hiring, firing, demoting, promoting, granting leave, and compensating”) with Deleon v. Kalamazoo Cnty. Road Comm'n, 739 F.3d 914, 91820 (6th Cir. 2014) (finding that lateral transfers can be considered adverse employment actions in specific circumstances).

182 Plaintiffs with disparate impact claims under Title VII must show that an employer is engaging in a practice that appears neutral but has a discriminatory effect on protected classes. See Griggs v. Duke Power Co., 401 U.S. 424, 429-30 (1971); 42 U.S.C. $§ 2000 \mathrm{e}-2(\mathrm{k})(1)(\mathrm{A})(\mathrm{i})$.

183 As discussed, Title VII harassment claims must show that the accused conduct is "severe or pervasive enough to alter terms or conditions of employment" and the harassment must "create an objectively hostile or abusive work environment - an environment that a reasonable person would find hostile or abusive," but need not lead to physical or psychological impairment. Harris v. Forklift Sys. Inc., 510 U.S. 17, 21-23 (1993).

184 Title VII retaliation claims have a lower burden than other Title VII claims. An "adverse action" in a Title VII retaliation context is not just confined to those that are related to employment or even those that occur in the workplace. Instead, an employee must only prove that the company did something that was harmful enough to dissuade a reasonable worker from making or supporting a charge of discrimination. Burlington N. \& Santa Fe Ry. Co. v. White, 548 U.S. 53, 67-68 (2006).

18542 U.S.C. $\$ 2000 \mathrm{e}-2(\mathrm{a})(1)$.

186 See Theresa M. Beiner, The Trouble with Torgerson: The Latest Effort to Summarily Adjudicate Employment Discrimination Claims, 14 NEV. L.J. 673, 673 (2014) ("In spite of court statements that employment discrimination cases are not well suited for summary judgment, summary judgment is often granted."). 
Many courts have set a very high bar when considering whether the claim meets this standard. ${ }^{187}$ A judge assessing the claim of a Black women plaintiff has the task of determining what an objectively "reasonable" person would find hostile, intimidating, threatening, and otherwise harmful. However, this is from the judge's perspective of what is reasonable for a person, while not necessarily considering the perspective of a reasonable Black woman in that position. ${ }^{188}$ This analysis is particularly concerning for Black women because it does not take into account the complexities of intersectional identities, where gender and racial subordination are compounded to create particular vulnerabilities to harassment, that is unlikely to be understood by the judge.

Critical race and feminist scholars have long challenged the reasonable person standard as "masquerade for the reasonableness of what the people in authority (white, male, and wealthy) believe to be reasonable." 189 While the reasonable person standard is said to be objective, judges, primarily white men, apply their own personal experiences, which can be plagued by biases and stereotypes, into assessment of plaintiffs' experiences. ${ }^{190}$ They may not only have difficulty understanding how it feels to be in the position of facing multiple forms of discrimination and harassment, but also may have biases that operate to favor the perpetrators. What they consider petty slights or trivial inconveniences from their privileged position can be life shifting for a Black woman in those shoes, considering her broader experiences of subordination and the structural realities that may make her uniquely vulnerable. ${ }^{191}$

To address these gaps, scholar Angela Onwuachi-Willig proposed that the reasonable person standard used in the hostile environment context should take into account the plaintiff's unique intersectional identity. ${ }^{192}$ For Black women, this could mean applying a reasonable Black woman standard, which may help a judge consider intersectionality theory rather than rely on his orientation towards reasonableness when considering the severity of a Black women worker's harassment. ${ }^{193}$ In 1993, the EEOC proposed guidelines that asked Courts to consider "the

187 Williams, supra note 55 (manuscript at 26-27); see Blough v. Hawkins Mkt., Inc., 51 F. Supp. 2d 858, 864 (N.D. Ohio 1999) (involving several incidents over a nine-month period, including patting plaintiff's butt, grabbing her crotch, trying to kiss her and engaging in self-stimulation in front of her all of which were isolated and insufficiently severe or pervasive in the court's view); Hannigan-Haas v. Bankers Life \& Casualty Co., No. 95 C 7408 , 1996 WL 650419, at*5 (N.D. Ill. Nov. 6, 1996) (holding an incident where a senior vice president pressed himself up against the plaintiff and tried to kiss her, touch her breasts and other body parts was insufficient as a matter of law because it was only one act).

${ }^{188}$ Williams, supra note 55 (manuscript at 26-27).

${ }^{189}$ Kristin Henning, The Reasonable Black Child: Race, Adolescence, and the Fourth Amendment, 67 AM. U. L. REV. 1513, 1529 (2018).

${ }^{190}$ Id.; Williams, supra note 55 (manuscript at 28).

191 Williams, supra note 55 (manuscript at 28). See generally Kimberlé Crenshaw, Mapping the Margins: Intersectionality, Identity Politics, and Violence against Women of Color, 43 STAN. L. REV. 1241 (1991).

${ }^{192}$ Angela Onwuachi-Willig, What About \#UsToo?: The Invisibility of Race in the \#MeToo Movement, 128 YALE L.J. F.105, 119 (2018), <https://www.yalelawjournal.org/pdf/Onwuachi-Willig_v3bzpvpm.pdf> (“Although support has long existed for a reasonable woman standard in harassment law, the standard must also be rooted in an intersectional and multidimensional lens in order to capture the different ways that women across intersectional categories may experience any particular event or events.").

193 Proponents of the reasonable woman standard hope that a gender-specific standard will help the courts enforce Congress's [Title VII] goal [to eliminate sex discrimination and gender disparities in the workplace]. They argue that a gender-specific standard can help reach this goal because "heightened sensitivity will bridge the gender gap on perceptions of harassing conduct." 
perspective of individuals of the claimant's race, color, religion, gender, national origin, age or disability."194 Although these guidelines were later withdrawn, the EEOC policy encouraged courts to consider the perspective of the victim when applying the reasonable person standard 195 and laid the foundation for some circuit courts to adopt a reasonable woman standard. ${ }^{196}$ The preference for a more individualized standard of reasonableness also leaves space for normative guidance and acknowledges the simple truth: "that the law is not self-applying, but always dependent on context." 197 The existing severe or pervasive standard reflects the fact that the baseline workplace is inherently one created and governed by white men, thus establishing the normative office environment from a white male-centric perspective, to the disadvantage of female complainants, including Black women. Modifying the severe or pervasive standard to judge the challenged conduct from the perspective of a reasonable Black woman would help to combat the white, male-dominated context in which Black woman plaintiffs experience harassment in the workplace and the white-male dominated judiciary in which they must assert their Title VII claims.

Ultimately, modifying the "objective" reasonable person standard to a particularized, reasonable Black woman standard in Title VII claims can better reduce racial and gender harassment in the workplace by attempting to acknowledge the unique context in which Black women workers face harassment. Although this article cannot fully address the various arguments and counter-arguments for a modified reasonable person standard, research documenting the intersections of race and sex dynamics in the workplace, which disproportionately impact Black woman workers, along with recent legal scholarship ${ }^{198}$ create the foundation for courts to consider applying a reasonable Black woman standard.

\section{FUTURE DIRECTIONS}

While there has been a wave of proposed reforms addressing sexual harassment claims in the last several years, many of those proposed reforms are inadequate to address the problems facing

V. Blair Druhan, Severe or Pervasive: An Analysis of Who, What, and Where Matters When Determining Sexual Harassment, 66 VAND. L. REV. 355, 367 (2013). Similarly, a reasonable Black woman standard may influence judges to have an increased sensitivity to intersectional discrimination that will improve their understanding of what may be perceived as harassing conduct to Black women workers.

194 SusAn M. OMILIAN \& JEAN P. KAMP, SEX-BASEd EMPlOYMENT Discrimination § 22:15 (2020) (citing EEOC Harassment Guidelines, to be published at 29 C.F.R. pt. 1609, 58 Fed. Reg. 51266 (Oct. 1, 1993), withdrawn, 59 Fed. Reg. 51396 (Oct. 11, 1995)).

195 Policy Guidance on Current Issues of Sexual Harassment, EEOC-CVG1990-8 (Mar. 19, 1990), <https://www.eeoc.gov/policy/docs/currentissues.html> (scroll down to "Guidance," C, 1) ("The reasonable person standard should consider the victim's perspective and not stereotyped notions of acceptable behavior.").

196 See Ellison v. Brady, 924 F.2d 872, 879 (9th Cir. 1991) ("We adopt the perspective of a reasonable woman primarily because we believe that a sex-blind reasonable person standard tends to be male-biased and tends to systematically ignore the experiences of women. The reasonable woman standard does not establish a higher level of protection for women than men ... . Instead, a gender-conscious examination of sexual harassment enables women to participate in the workplace on an equal footing with men. By acknowledging and not trivializing the effects of sexual harassment on reasonable women, courts can work towards ensuring that neither men nor women will have to 'run a gauntlet of sexual abuse in return for the privilege of being allowed to work and make a living."'); see also Nicole Newman, The Reasonable Woman: Has She Made a Difference?, 27 B.C. THIRD WoRLD L.J. 529 (2007)

197 Henning, supra note 188, at 1534 (citing Victoria Nourse, After the Reasonable Man: Getting over the Subjectivity/Objectivity Question, 11 NEW. CRIM. L. REV. 33, 35 (2008)).

198 Anna I. Burke, "It Wasn't That Bad”: The Necessity of Social Framework Evidence in Use of the Reasonable Woman Standard, 105 IOWA L. REV. 771,790-93, 798 (2020). 
Black women. ${ }^{199}$ While advocates for workplace reform have been acknowledging the importance of intersectionality, the proposed bills at the state level don't recognize it, as most only address gender equity and not related racial equity. For example, no state has passed a workplace sexual harassment bill using the words "intersectional" or "intersectionality." 200 And very few of the proposed policy reforms address race. ${ }^{201}$ This omission by state legislators is likely strategic, as activists are aware of the structural and political realities that shape which bills are passed and which are not. ${ }^{202}$ As a social movement, MeToo, like other feminist and antiracist movements, has marginalized the abuses faced by women of color. ${ }^{203}$ Women of color's experiences are dissimilar from those of the high status white women who have become the face of the \#MeToo movement, so its resulting reforms do not inherently take their needs into account. ${ }^{204}$ Instead, many of the reforms which have actually passed were those championed by white women and garnering significant media attention, attracting them to lawmakers. ${ }^{205}$

For example, very few of the bills protect domestic and home care workers, change rigid statutes of limitations, reduce hurdles for bringing intersectional claims, or address damage caps that make it difficult to find an attorney and less worthwhile to file a claim. ${ }^{206}$ And only a handful of states introduced legislation seeking to lower the stringent "severe or pervasive" standard for harassment claims at the state level. ${ }^{207}$ These shortcomings must be addressed in order to have real, substantive reform to antidiscrimination laws and proper treatment of intersectional claims.

California has led the way in enacting reform that will have a more meaningful impact for Black women. The state has altered the standard so that a single incident of sexual harassment is

199 To examine the actual and potential policy changes following \#MeToo, my research team reviewed all proposed, passed, and pending state and federal legislation that explicitly addressing sexual harassment and gender equity from October 2016 to December 2020. Since October 2016, almost a thousand bills have been introduced across nearly all fifty states, plus the District of Columbia.

200 Methodology: using Legiscan, we performed a legislative search for each state for the legislative sessions incorporating bills introduced from October 2016-present (2017, 2018, 2019, and 2020 legislative sessions). Our initial search was: "sexual harassment" OR "equal pay" OR "sexual misconduct" OR "gender equity" OR "gender equality OR "intersectional" OR "intersectionality." Additional search terms varied depending on the type of bill, including, but not limited to "statute of limitations," "discriminatory harassment," "workplace harassment," "severe or pervasive," Farragher," "cause of action," "damages," "remedies," among others. From there, we searched each individual bill to see if there were any parts of the bill that applied generally to harassment, equal pay, gender equity, whether it was through increased awareness, mandatory training, or some other expansion or limitation on current law.

${ }^{201}$ J.B. Williams Harassment Dataset (2021). Only about thirty of the almost 1,000 bills introduced in state legislatures dealing with workplace harassment incorporated the words "race," (twenty) "minority," "minorities," or "ethnicity." None of the bills introduced at the state level incorporated the words "immigrant" or "women of color."

202 Williams, supra note 55 (manuscript at 35-45).

${ }^{203}$ Id. (manuscript at 1-8); Onwuachi-Willig, supra note 191.

${ }^{204}$ Williams, supra note 55 (manuscript at 52).

${ }^{205} \mathrm{Id}$.

206 J.B. Williams Harassment Dataset, supra note 200. Bills concerning legal remedies to sexual harassment make up 15 percent of all bills introduced, but only 0.02 percent of all bills passed; Further, plaintiffs' attorneys will not take on intersectional claims of Black women, because they are aware that courts are often hostile to these types of claims and thus they are unlikely to lead to damages.

${ }^{207}$ Id. Only seven states (Virginia, Minnesota, New York, North Carolina, New Jersey, Connecticut, California) introduced bills to lower the severe or pervasive standard. These provisions were only passed in New York and California. 
sufficient to create a hostile work environment. ${ }^{208}$ Additionally, California has adopted a "totality of the circumstances" standard in lieu of "severe or pervasive," and has determined that harassment is sufficient if it has "unreasonably interfered" with the employee's work performance and made it more difficult for the employee to do their job. ${ }^{209}$ As part of its reform, California enacted a provision that specifies "harassment cases are rarely appropriate for disposition on summary judgment." ${ }^{10}$ New York law has also provided that an employee need not compare their treatment to that of another employee in order to state a claim. ${ }^{211}$ Employers can assert a defense to such a claim if they can show that the harassing conduct did not rise above what a reasonable person in the same protected class would consider petty slights or trivial inconveniences. ${ }^{212}$

State law advocates in Virginia, like New York, have also attempted to remedy these inequities by introducing harassment bills more generally tailored to address problems facing Black women and other individuals with intersectional claims. ${ }^{213}$ The "Safe and Thriving Workplace Act" provides a statutory definition of workplace harassment in Virginia employment discrimination law. The bill clarifies that workplace harassment shall be viewed in the "aggregate" "with varying types" and "based on multiple characteristics" viewed in totality, rather than in isolation. ${ }^{214}$ The bill also extends Virginia's anti-discrimination law to employers with five or more employees ${ }^{215}$ and allows for awards of "attorney fees and costs" to include reasonable litigation expenses. ${ }^{216}$

It is too early to tell, given the highly divided Congress, but there is also greater possibility for federal reform with the Biden-Harris administration. For example, in September 2020, the House of Representatives passed the Creating a Respectful and Open World for Natural Hair (CROWN) Act, which would prohibit discrimination based on a person's hair texture or hairstyle if that style or texture is commonly associated with a particular race or national origin. ${ }^{217}$ The CROWN Act would legally prohibit corporate grooming policies that unfairly penalize Black women in the workplace when wearing their hair naturally or in styles like braids and knots. ${ }^{218}$ With a narrow Democratic majority, the CROWN Act may see movement in the 117th Congress. The "Justice for All Act," introduced in October 2020, is an expansive bill to amend Title VII of the Civil Rights Act of $1964 .^{219}$ This type of bill could also change the statutory language to explicitly read that

${ }^{208}$ CAL. GOV’T CODE $\S 12923$ (b) (West 2018); This is critical because many state and federal courts have been requiring that harassment be severe and pervasive, so that no matter how severe, it would not be considered to create a hostile environment if it occurred only once.

${ }^{209}$ Id. $\S 12923(\mathrm{c})$.

${ }^{210}$ Id. $\$ 12923(\mathrm{e})$.

${ }^{211}$ A. $8421, \S 13$, Assemb. 2019-2020 Reg. Sess. (N.Y. 2019).

${ }^{212} \mathrm{Id}$.

${ }^{213}$ H.B. 2155, 2021 Reg. Sess. (Va. 2021).

${ }^{214} I d$.

${ }^{215} \mathrm{Id}$.

${ }^{216} I d$.

${ }^{217}$ H.R. 2116, 117th Cong. (2021) (Crown Act); California (S.B. 188 (2019)), New York (A.B. 7797A (2019)), New Jersey (N.J. StaT. ANN. § 10:5-5 (West 2020)), Maryland (S.B. 531 (2020)), Virginia (S. 50 (2020)), Colorado (H.B. 1048 (2020)), Washington (H.B. 2602 (2020)), Connecticut (H.B. 6515 (2021)), and Delaware (S.B. 32 (2021)) have all passed similar provisions banning hair discrimination. Twenty-three states have introduced CROWN legislation. See About, THE CROWN ACT, https:/www.thecrownact.com/about (last visited June 2, 2021).

${ }^{218}$ About, supra note 216.

219 H.R. 8698, 116th Cong. (2020). The bill would: overturn the Supreme Court's decision in Alexander v. Sandoval, 532 U.S. 275 (2001) (prohibited private individuals from challenging specific types of disparate impact 
more than one trait could be used in an employment discrimination or harassment claim. ${ }^{220}$

Given confusion and inconsistency across courts, at a minimum, the EEOC must issue more specific guidance on how courts should interpret federal law to analyze intersectional claims. ${ }^{221}$ While the current EEOC guidance clarifies that intersectional discrimination is a viable cause of action, it does not provide examples of what this may look like or what analytical framework may be best suited for the unique types of harassment intersectional plaintiffs face. Additional guidance is necessary to ensure plaintiffs, employers, attorneys, and judges all understand the concept of intersectionality and to provide more clarity around how these claims should be analyzed.

\section{CONCLUSION}

Intersectional discrimination and harassment are not one size fits all, and rigid analytical frameworks that rely on discrete characteristics and narrow tests do not work. Moving forward, advocates focused on improving employment law and policy to better protect Black women must encourage a more holistic, yet nuanced way to analyze the multitude of ways Black women experience intersectionality. New approaches should better comport with intersectionality theory by not constraining plaintiffs to place one trait, typically sex, above another, race. Instead, legal frameworks must recognize how both protected traits, race and sex, can combine in a myriad of ways to create a unique experience for Black women in the workplace. A more flexible approach is needed that will force lawyers, law students, and judges to see the whole person rather than picking apart a person's identity in such a way that minimizes experiences of discrimination.

Like many changes, reform to better protect Black women will be an uphill battle, with intersectional approaches facing hostility in the courts using labels such as "super remedy" "many headed hydra" "kitchen sink" This resistance improperly characterizes Black women as being

discrimination, such as state regulations with the effect of discriminating against classes of individuals), giving a private right of action under Title VI to allow private lawsuits based on evidence of disparate impact; codify the Supreme Court's decisions in Oncale v. Sundowner Offshore Services, 523 U.S. 75 (1998) and Price Waterhouse v. Hopkins, 490 U.S. 228 (1989), prohibiting sex discrimination based on sexual orientation, gender identity, and sex stereotypes; overturn Supreme Court precedent interpreting the Federal Arbitration Act to broadly preempt rights and remedies established under state and federal law, which would allow states to prohibit mandatory arbitration provisions without worrying about federal preemption; overturn the Supreme Court's decisions in Faragher v. City of Boca Raton, 524 U.S. 775 (1998) and Burlington Industries, Inc. v. Ellerth, 524 U.S. 742 (1998) (allowing employers to avoid liability for sexual harassment merely because they have an anti-harassment policy in place or because the employee did not take "formal" steps within the organization to report or prevent the harassment); reverse Supreme Court precedent and allow plaintiffs who win a lawsuit through a settlement to collect pre-trial attorney's fees; and codify that dress codes and grooming policies that prohibit any natural presentation of Black hair or any hairstyles associated with race is race discrimination.

220 Pappoe, supra note 25; Areheart, supra note 25; Rosalio Castro \& Lucia Corral, Women of Color and Employment Discrimination: Race and Gender Combined in Title VII Claims, 6 LA RAZA L.J. 159 (1993).

${ }^{221}$ Title VII prohibits discrimination not just because of one protected trait (e.g., race), but also because of the intersection of two or more protected bases (e.g., race and sex). For example, Title VII prohibits discrimination against African American women even if the employer does not discriminate against White women or African American men. Likewise, Title VII protects Asian American women from discrimination based on stereotypes and assumptions about them "even in the absence of discrimination against Asian American men or White women." EEOC Compliance Manual $\S 15(\mathrm{IV})(\mathrm{C})$, supra note 50. The law also prohibits individuals from being subjected to discrimination because of the intersection of their race and a trait covered by another EEO statute - e.g., race and disability, or race and age. Id. 
confused about what they are experiencing, divisive, or asking for a special handout. ${ }^{222}$ However, critique of the MeToo movement as being about white women brought greater unity and understanding of critical issues of intersectionality, and the movement for racial justice has also opened the world's eyes to why we must also "say her name" and acknowledge the often misunderstood and forgotten injustices faced by Black women.

${ }^{222}$ DeGraffenreid v. Gen. Motors Assembly Div., 413 F. Supp. 142, 145 (E.D. Mo. 1976), aff'd in part, rev'd in part on other grounds, 558 F.2d 480 (8th Cir. 1977) ("The prospect of the creation of new classes of protected minorities, governed only by the mathematical principles of permutation and combination, clearly raises the prospect of opening the hackneyed Pandora's box.”); Judge v. Marsh, 649 F. Supp. 770, 780 (D.D.C. 1986). 